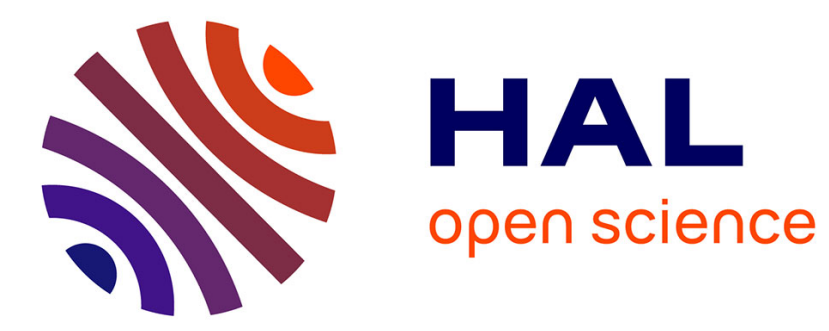

\title{
Relation between activator ratio, hydration products and mechanical properties of alkali-activated slag
}

Ugo de Filippis, Elodie Prud'Homme, Sylvain Meille

\section{To cite this version:}

Ugo de Filippis, Elodie Prud'Homme, Sylvain Meille. Relation between activator ratio, hydration products and mechanical properties of alkali-activated slag. Construction and Building Materials, 2021, 266, pp.120940. 10.1016/j.conbuildmat.2020.120940 . hal-03378765

\section{HAL Id: hal-03378765 \\ https://hal.science/hal-03378765}

Submitted on 14 Oct 2021

HAL is a multi-disciplinary open access archive for the deposit and dissemination of scientific research documents, whether they are published or not. The documents may come from teaching and research institutions in France or abroad, or from public or private research centers.
L'archive ouverte pluridisciplinaire HAL, est destinée au dépôt et à la diffusion de documents scientifiques de niveau recherche, publiés ou non, émanant des établissements d'enseignement et de recherche français ou étrangers, des laboratoires publics ou privés. 


\title{
Relation between Activator Ratio, Hydration Products and Mechanical Properties of Alkali-activated Slag
}

Ugo De Filippis ${ }^{\mathrm{a}}$, Elodie Prud'homme ${ }^{\mathrm{a}, *}$, Sylvain Meille ${ }^{\mathrm{a}}$

\author{
${ }^{a}$ Univ Lyon, INSA Lyon, MATEIS UMR 5510, 7 avenue Jean Capelle, 69100 Villeurbanne, France \\ *Corresponding author: elodie.prudhomme@insa-lyon.fr
}

The use of cement substitute, such as alkali-activated slag, is of great interest in the field of earth-based construction materials to preserve their environmental benefit. Nonetheless, the cationic activity of clayey particles of earth-based materials induces new issues by affecting the alkaline conditions in which slag is activated. This work aims to present how alkaline conditions modify the nature and the amount of hydrates formed, the kinetics for reaction and the resulting mechanical properties. A minimum of $5 \mathrm{wt}$ \% of activator with respect to the slag was needed to trigger consolidation of the samples within the first 24 hours, while an activator content of $15 \%$ led to an excess of sodium, especially remarkable at early age. Besides, hydration kinetics were followed in situ during the first 3 days by infrared spectroscopy. The formation of portlandite and hydrotalcite-like hydrates were only observable from $10 \%$ of activator and the presence of hydrotalcite is correlated with an increase in mechanical properties. Finally, these results are of interest for the formulation of earth-based materials by predicting hydrated phases formed during slag activation depending on alkaline conditions.

Keywords: Compressive strength, In-situ FTIR, Thermal analysis, Hydrates assemblage, SEMEDX 


\section{Introduction}

Grounded Blast Furnace Slag (GBFS) is a steel industry by-product commonly used as Ordinary Portland Cement (OPC) substitute because of its lower environmental footprint. Reducing OPC consumption, whose production is responsible for 5 to $7 \%$ of worldwide carbon dioxide emissions [1,2], is a critical issue and the use of alternative cementitious binder is an attractive option. Blast furnace slag presents a latent hydraulicity, meaning that under specific activation conditions it can dissolve and lead to the formation and growth of hydrates similar to those observed during OPC hydration [3]. This opens the way for applications as building materials, soil stabilization, and reinforcement of earth-based concrete or bricks [4,5].

Soil stabilization with binder adjunction, as OPC or activated slag, consists in the addition of a hydraulic binder to a soil to obtain a hydrated composite material. Interactions between binder's hydrates and soil's particles are of two kinds: physicochemical interactions between hydrated gel and clays particles surface, and pozzolanic reactions between calcium hydroxide potentially released during hydration and clay minerals $[4,6]$. To better understand these interactions a detailed knowledge of the binder hydration, of the microstructure formed and of the composition of hydrated phases are needed.

Slag hydration has been largely studied in literature [3,7-25,28,30-32,35-39]. As for OPC, it starts with the dissolution of the anhydrous grains into dissolved silicate, aluminate and cationic (sodic or calcic) species. Once these species reach a sufficient concentration in the interstitial solution, they start to precipitate into hydrated phases. This precipitation, lowering the concentration of dissolved species, favors further dissolution of anhydrous grains. However, unlike OPC, slag dissolves very slowly into pure water [7], so that its hydration kinetic is very slow [8], compromising its use as hydraulic binder. To accelerate the initial dissolution an alkaline activator is needed. This activation can be calcic, sodic or sulfatic and usually involves a pH value above $12.5[9,26]$. The cationic species of the activator act as network modifiers and induce a faster dissolution of silicate and aluminate species that compose the glassy structure of anhydrous slag [27]. Cationic species could also prevent the precipitation of calcium aluminate hydrate gel on the grain surface that could hinder further dissolution or ionic diffusion [27]. Previous studies showed that slag's hydration largely depends on its chemical composition, on its particle size distribution, and on the nature of the activation mix $[3,9,28-$ $30,10-16,26]$. A detailed study of the activation of one particular slag should then be made in order to characterize the hydrated products formed depending on activation conditions. 
Currently, the most commonly used mixtures for slag activation are composed of sodium hydroxide and/or sodium silicate, mainly because they lead to the highest properties after activation, such as compressive strength $[31,32]$. Sodium silicate usually leads to the highest mechanical properties [17], but its production process negatively impacts the environmental footprint of alkali-activated binders $[18,33,34]$. The influence of the activator concentration in the initial mix has also been investigated. It seems that no consensus has been reached since some authors describe the optimum range of sodium hydroxide content between 3 to $5 \%$ of slag mass $[19,20,35]$ while others have shown an increase of hydrated slag's mechanical performance with sodium hydroxide concentration until more than 6 to $10 \%$ of slag mass [36,37]. Besides, identification of hydrated phases has been mainly studied in a small range of activator ratio, typically between 2 and $6 \mathrm{wt}$.\%. Sodium hydroxide activation mainly favors the precipitation of hydrated phases such as calcium silicate hydrates and calcium-aluminum silicate hydrates - C-S-H and C-A-S-H respectively - [21,26,29,38], calcium aluminum hydrate gel $(\mathrm{CAH})[22,39]$ and hydrotalcite $\left(\mathrm{Mg}_{\mathrm{w}} \mathrm{Al}_{\mathrm{x}} \mathrm{CO}_{3}(\mathrm{OH})_{\mathrm{y}} \cdot \mathrm{z}\left(\mathrm{H}_{2} \mathrm{O}\right)\right)$ [13,23] with GBFS containing high amount of $\mathrm{MgO}$ (> 5\% wt.) [11,24]. In the objective of soil stabilization, cationic activity of clayed materials allow cationic exchange between clay sheets and interstitial pore solution [40]. This changes the activator concentration and alkaline conditions in which slag is activated. A precise knowledge of the impact of alkaline conditions on slag hydration is therefore needed to understand how cationic activity of clays could disturb slag activation.

The aim of this study is to characterize slag hydration under different alkaline conditions, at early age and in the long term, to understand the impact of initial activator content on the formation and evolution of hydrated phases formed. To take into account these activator's variations, sodium hydroxide is used as activator, considering a large range of $\mathrm{Na}_{2} \mathrm{O}$ to slag mass ratios, from 1.25 to $15 \%$ of slag mass. These activation rates were chosen because of the end application for earth building materials, which will result in cation exchange with clays. The microstructural characterization, as a function of curing time until 90 days, will then be related to compressive strength measurements.

\section{Material and Methods}




\subsection{Materials}

The slag used in this study is a GBFS supplied by ECOCEM France whose composition is given in Table 1. Its specific surface area (Blaine) is $4450 \mathrm{~cm}^{2} / \mathrm{g}$ and its median diameter $\left(\mathrm{d}_{50}\right)$ is $11 \mu \mathrm{m}$. Basicity of this slag, characterized by $(\mathrm{CaO}+\mathrm{MgO}) / \mathrm{SiO}_{2}$ molar ratio, is of 1.19 , an indicator of its good reactivity since this ratio is larger than 1 [25].

Table 1: Chemical composition (oxides weigth\%) of the slag

\begin{tabular}{|l|c|c|c|c|c|c|}
\hline Elements & $\mathbf{C a O}$ & $\mathbf{S i O}_{2}$ & $\mathbf{A l}_{2} \mathbf{O}_{3}$ & $\mathbf{M g O}$ & $\mathbf{S O}_{3}$ & Others \\
\hline Rate $(\%)$ & 42.0 & 35.3 & 10.9 & 7.5 & 2.3 & 2.0 \\
\hline
\end{tabular}

Activating solutions were prepared by dissolving different amounts of sodium hydroxide pellets (purity 99.9\%, Fisher Scientific) in distilled water, as shown in Table 2. Solutions were used after that complete dissolution and cooling to room temperature $\left(25 \pm 2^{\circ} \mathrm{C}\right)$ was achieved.

\subsection{Specimen preparation}

Samples were prepared mixing anhydrous slag and activating solutions with a constant water to slag ratio (W/S) equal to 0.4 for each formulation. Pastes were formulated to achieve four different $\mathrm{Na}_{2} \mathrm{O}$ to slag weight ratios (A/S): $1.25,5,10$, and $15 \%$, corresponding to $1,4,8$, and $12 \mathrm{M} \mathrm{NaOH}$ activating solution respectively (Table 2). After a constant hand mixing time ( $1 \mathrm{~min}$ ), fresh pastes are poured into cylindrical molds of $2 \mathrm{~cm}$ diameter and $4 \mathrm{~cm}$ height. Molds are kept closed to stay under endogenous conditions and avoid water evaporation or drying gradient. Samples are demolded after 24 hours, immediately and individually sealed in tightly closed plastic film to stay under endogenous conditions before testing and kept at room temperature. Three samples of each formulation were prepared and tested at 24 hours, 7, 28 and 90 days respectively. All characterization methods were performed at the mentioned curing times and averaged on three samples. 
Table 2: Activating solution characteristics used for each initial activator ratio

\begin{tabular}{ccccc}
\hline Activator & \multicolumn{5}{c}{$\mathrm{Na}_{2} \mathrm{O}$} \\
\hline Activator / Slag (wt.\%) & 1.25 & 5 & 10 & 15 \\
Water / Slag (wt.\%) & 0.4 & 0.4 & 0.4 & 0.4 \\
[Na $\mathbf{N a}^{+}$(M) & 1.01 & 4.03 & 8.06 & 12.1 \\
pH value & 13.2 & 13.6 & 13.8 & 13.9 \\
\hline
\end{tabular}

\subsection{Characterization Methods}

Mechanical properties were determined by uniaxial compressive tests using a Zwick device equipped with a $100 \mathrm{kN}$ load cell (class 0.5 ). The crosshead speed was set to $0.3 \mathrm{~mm} / \mathrm{min}$.

Fourier Transform Infrared spectroscopy (FTIR) were performed on a TermoFisher Scientific IS50 device using Attenuated Total Reflection (ATR) mode from 4000 to $450 \mathrm{~cm}^{-1}$, with a spectral resolution of $0.5 \mathrm{~cm}^{-1}$ and averaged on 32 scans. Data were acquired with Omnic Series software with the same parameters for both the tests on hydrated samples and for the in situ experiments. Data were analyzed using Omnic Series software with a baseline correction treatment. All spectra were normalized with respect to the water absorbance band at $1640 \mathrm{~cm}^{-}$ 1

For the characterization of hydrated paste at each curing time, sample pieces were used without prior grinding. In situ infrared experiments were conducted using a plastic mold fixed on ATR tool's plate and centered on the crystal (Figure 1). It allows pouring slag paste onto analysis area just after mixing ( 1 ' mixing +45 " pouring). A piston inserted into the mold maintained a constant pressure on the sample and ensured a good contact with ATR crystal. Water evaporation was limited using a water tank around the mold and the whole system was covered with a plastic film. Scans were obtained using the same parameters as described hereinabove with a time step of 1 minute during 3 days. The first (after 1min) and the last (after 3 days) spectra obtained with this technique are available for all formulations in the supplementary material. 


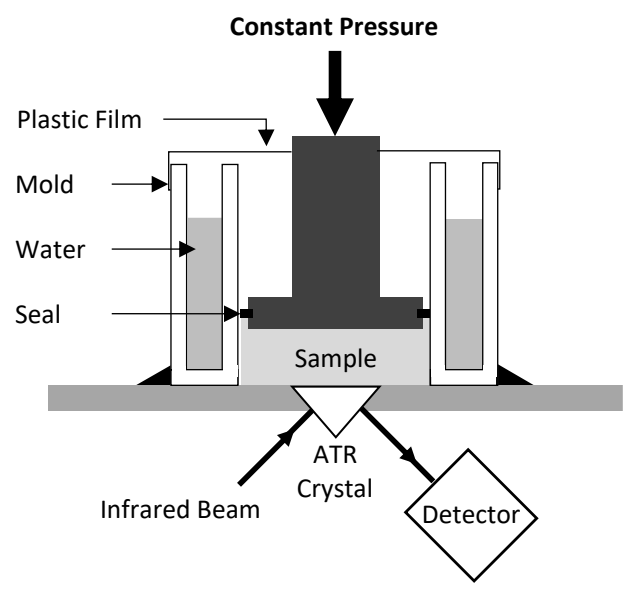

Figure 1: Scheme of infrared (ATR) setup for in situ follow-up of hydration

Thermogravimetric (TGA) and differential thermal analysis (DTA) were performed on a Setaram Setsys Evolution device (Caluire, France) up to $1050^{\circ} \mathrm{C}$ with a heating rate of $10^{\circ} \mathrm{C} / \mathrm{min}$ and under dry air with a fixed flow of $20 \mathrm{~mL} / \mathrm{min}$. A $50.0 \pm 0.5 \mathrm{mg}$ mass is placed in a closed alumina crucible. Measurements data are analyzed with Setsoft software. Baseline corrections are operated with a blank measurement realized on an empty alumina crucible.

X-ray diffraction patterns were acquired with a D8 Advance diffractometer (Brucker, Germany) using $\mathrm{CuK} \alpha$ radiation $(\lambda \mathrm{K} \alpha=0.154186 \mathrm{~nm})$, an acquisition step of $0.02^{\circ}(2 \theta)$ between $5^{\circ}$ and $65^{\circ}(2 \theta)$, and a dwell time of $1.3 \mathrm{~s}$. The analysis is carried out on a plane surface of the sample that has been polished beforehand. Data analyses were performed using EVA software with background and $\mathrm{K} \alpha_{2}$ corrections, as well as scale normalization for comparison between the samples. Identification of crystalline phases was made by comparison with PDF standards (Powder Diffraction Files) from ICDD (International Centre for Diffraction Data).

Scanning electron microscopy (SEM) observations were performed on a Vega 3 SEM (Tescan, Czech Republic) equipped with a tungsten filament and coupled to energy dispersive X-Ray spectroscopy (EDX). Observations were made on gold coated samples. Images acquisition was performed in back scattering electron (BSE) mode, with an acceleration voltage of $5 \mathrm{kV}$. EDX acquisitions were performed with an acceleration voltage of $15 \mathrm{kV}$ and using an Oxford Instruments INCA x-act. Data analyses were performed using Aztec One software series. 
FTIR, TG-DTA, XRD and SEM tests were performed on grinded sample's pieces without using any hydration stop process to avoid chemical or microstructural damages. All tests were then performed after the exact curing time delay.

\section{Results}

\subsection{Mechanical Properties}

a)

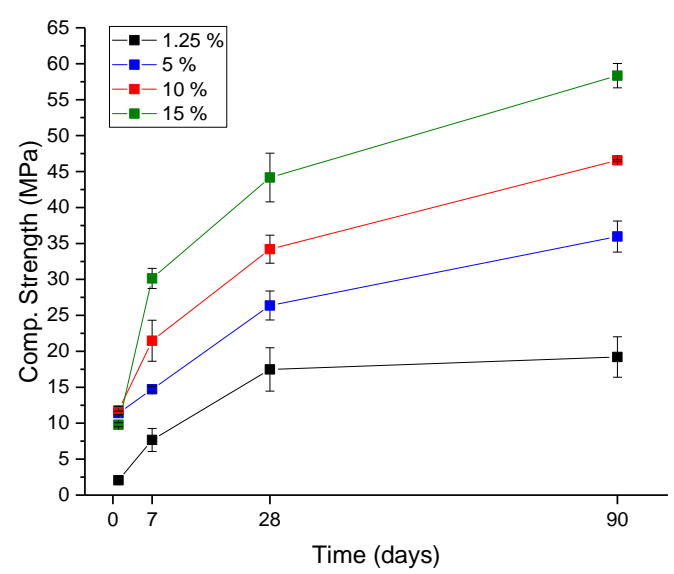

b)

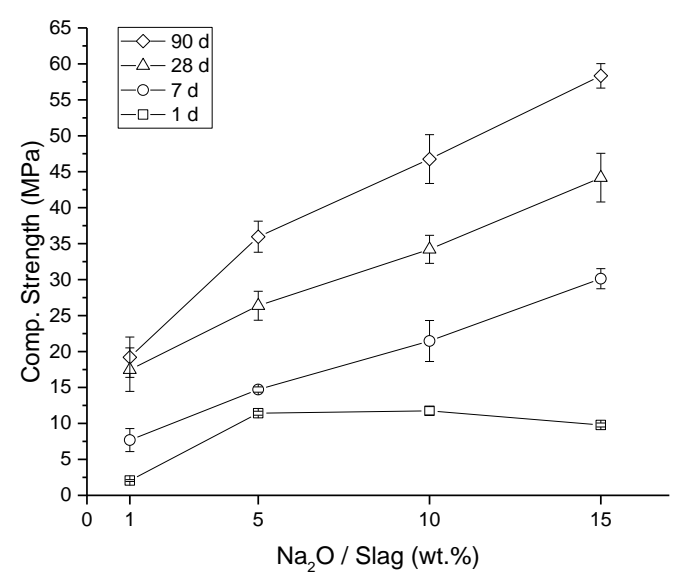

Figure 2: Evolution of compressive strength (a) for each $\mathrm{A} / \mathrm{S}$ with time, and (b) for different curing time as a function of activator ratio

Evolution of compressive strength with time is displayed in Figure 2.a for different A/S ratios. After 1 day of curing, strength development is very low for $1.25 \%$ of activator and samples are almost impossible to demold properly because cohesion is not sufficiently achieved. For samples with an A/S ratio superior to $1.25 \%$, cohesion is achieved and all samples present a compressive strength close to $10 \mathrm{MPa}$. Above this threshold, the ratio doesn't seem to noteworthy impact strength development after 24 hours [41]. This observation is made more obvious when compressive strength is plotted against sodium to slag ratio for each curing time (Figure 2.b) since for 1 day of curing strength development does not appear to be linked to activator content above $1.25 \%$. From 7 days, compressive strength increases for each formulation, this increase being proportional to the sodium concentration. Between 1 and 7 days, compressive strength increases by a factor of 1.3, 1.8 and 3.0 for 5,10 and $15 \%$ respectively. As it can be seen in Figure 2.b, compressive strength varies linearly with initial $\mathrm{A} / \mathrm{S}$ at 7 and 28 days. This linear trend is still noted at 90 days except for $1.25 \%$ sample, since compressive strength doesn't evolve anymore after 28 days for this formulation (Figure 2.a). 
Strength development above 1 day of curing strongly depends on A/S in the case of sodium hydroxide activation, especially regarding long term performances.

\subsection{Early Age Hydration}

Figure 3 shows FTIR spectra collected from anhydrous slag and from all hydrated samples after $24 \mathrm{~h}$ of curing. Considering the spectrum of anhydrous slag, the broad band noted between 1550 - $1400 \mathrm{~cm}^{-1}$ and centered on $1475 \mathrm{~cm}^{-1}$ (Figure 3.b) is attributed to $\mathrm{CO}_{3}{ }^{2-}$ vibrations in different configurations [42-46], revealing the presence of carbonated species. The broad dome visible between 1050 and $750 \mathrm{~cm}^{-1}$ (Figure 3.a) is mainly attributed to silico-aluminate groups which form the main structure of anhydrous slag. Finally, the presence of a band at $875 \mathrm{~cm}^{-1}$, attributed to $\mathrm{CO}_{3}{ }^{2-}$ vibrations in calcium carbonates $[42,44-46]$, confirm the presence of $\mathrm{CaCO}_{3}$ phases.

(b)

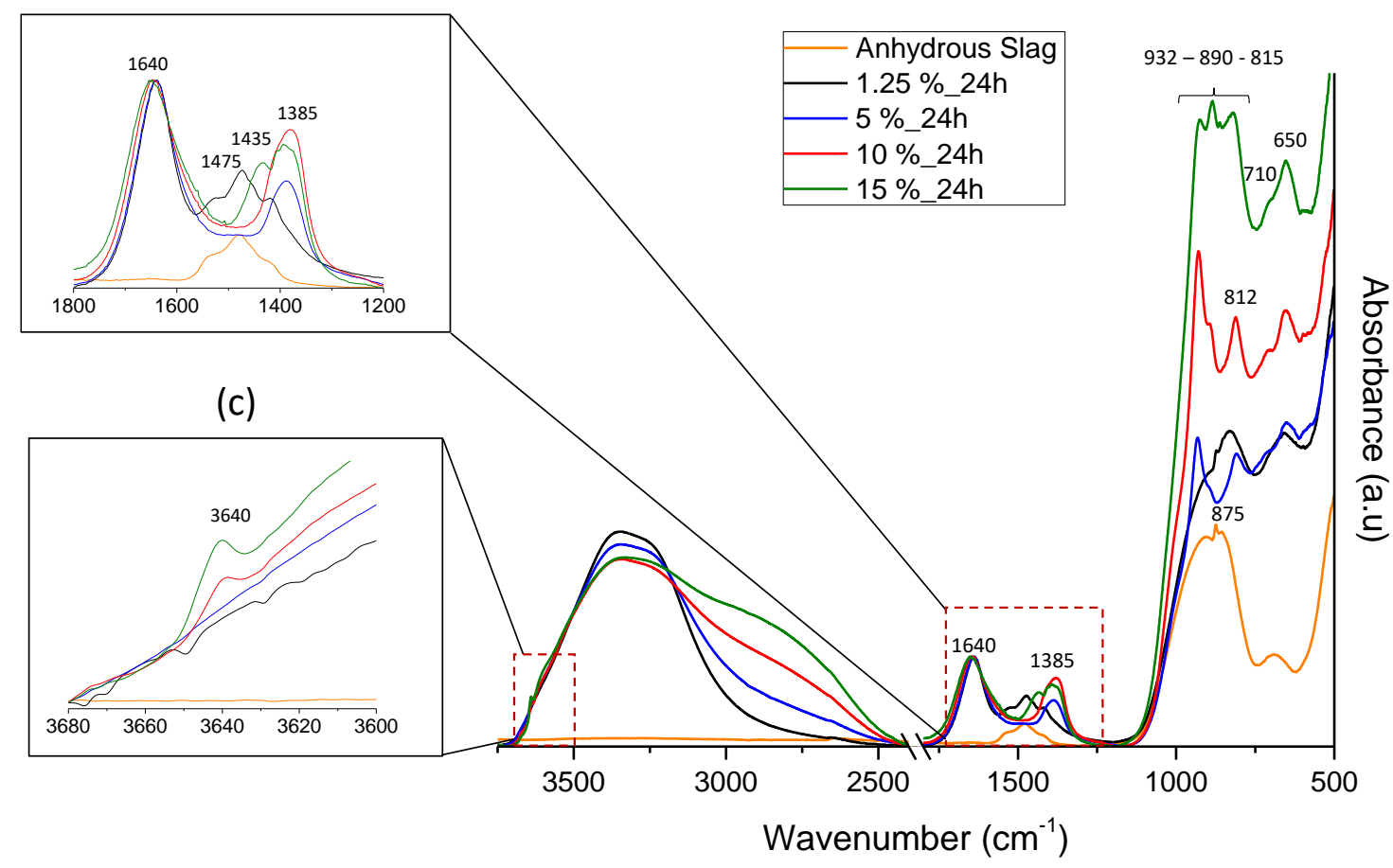

Figure 3: (a) FTIR spectra of anhydrous slag and hydrated samples for each A/S after 24 hours of curing, between 500 $3750 \mathrm{~cm}^{-1}$, (b) zoom between $1200-1800 \mathrm{~cm}^{-1}$ and (c) zoom between $3600-3680 \mathrm{~cm}^{-1}$

Spectra of activated samples show a broad band between $3650-2600 \mathrm{~cm}^{-1}$ typical of O-H stretching vibration of hydroxyl groups from hydrated phases and from free water, the latter 
being also visible at $1640 \mathrm{~cm}^{-1}$. The broad $\mathrm{OH}$-band clearly tends to shift to lower frequencies while activator content increases. This shift is due to the dissolution of sodium hydroxide in the activating solution. It is related to $\mathrm{Na}-\mathrm{OH}$ vibrations [47] and a reduction of the $\mathrm{OH}-\mathrm{O}$ bound length [48] due to the structuration of water involved by the presence of soda. The specific band of portlandite $\left(\mathrm{Ca}(\mathrm{OH})_{2}\right)$ at $3640 \mathrm{~cm}^{-1}$, attributed to $\mathrm{Ca}-\mathrm{OH}$ vibrations [46], is clearly visible for samples with activator content above 10\% (Figure 3.c) and its absorbance increases with sodium content. This result is consistent with those reported in the literature with an A/S of $8 \%$ [49]. Considering carbonates vibrations region (Figure 3.b), the specific bands of anhydrous state centered on $1475 \mathrm{~cm}^{-1}$ are visible for $1.25 \%$ of activator, so that anhydrous carbonated species have not been dissolved. However, for an activator content superior to $1.25 \%$, bands at 1385 and $710 \mathrm{~cm}^{-1}$ differ from those of anhydrous slag, revealing a change in carbonates configuration [50]. These bands are close to those observed for dissolved carbonate anions $\mathrm{CO}_{3}{ }^{2-}$ [43]. This is attributed to an attack of calcium carbonate phases which can leads to its partial or total dissolution. For the $15 \%$ sample, a band at $1435 \mathrm{~cm}^{-1}$ is attributed to the presence of hydrated sodium carbonates, $\mathrm{Na}_{2} \mathrm{CO}_{3} \cdot \mathrm{x}\left(\mathrm{H}_{2} \mathrm{O}\right)$ [32,42]. The formation of calcium silicate hydrates potentially containing high amount of aluminum, C-A-S-H [51], is revealed in the lowfrequency region $\left(500-1200 \mathrm{~cm}^{-1}\right)$ by the bands at 932, 812 and $650 \mathrm{~cm}^{-1}$ [46,51-58] (Figure 3.a). The relatively low main wavenumber associated to asymmetric stretching vibration of Si$\mathrm{O}-\mathrm{T}\left(\mathrm{T}=\mathrm{Si}\right.$ or $\mathrm{Al}$ ) bonds at $932 \mathrm{~cm}^{-1}$ could be associated to relatively depolymerized C-A-S-H, mainly composed of $\mathrm{Q}^{1}$ or $\mathrm{Q}^{2}$ tetrahedral units, either due to high calcium to silicon $(\mathrm{C} / \mathrm{S})$ ratio [46], sodium uptake [59] or to high amount of aluminum incorporation [46,51,52,60]. It can be noted that the bands associated to C-A-S-H gel do not shift with increasing activator content. The band at $890 \mathrm{~cm}^{-1}$ is not visible for $5 \%$ sample, slightly present for $10 \%$, and well defined for $15 \%$, indicating significant differences in the hydrated phases formed. This band is attributed to the formation of a hydrotalcite-like phase noted at early age only when A/Sis above $10 \%$. 


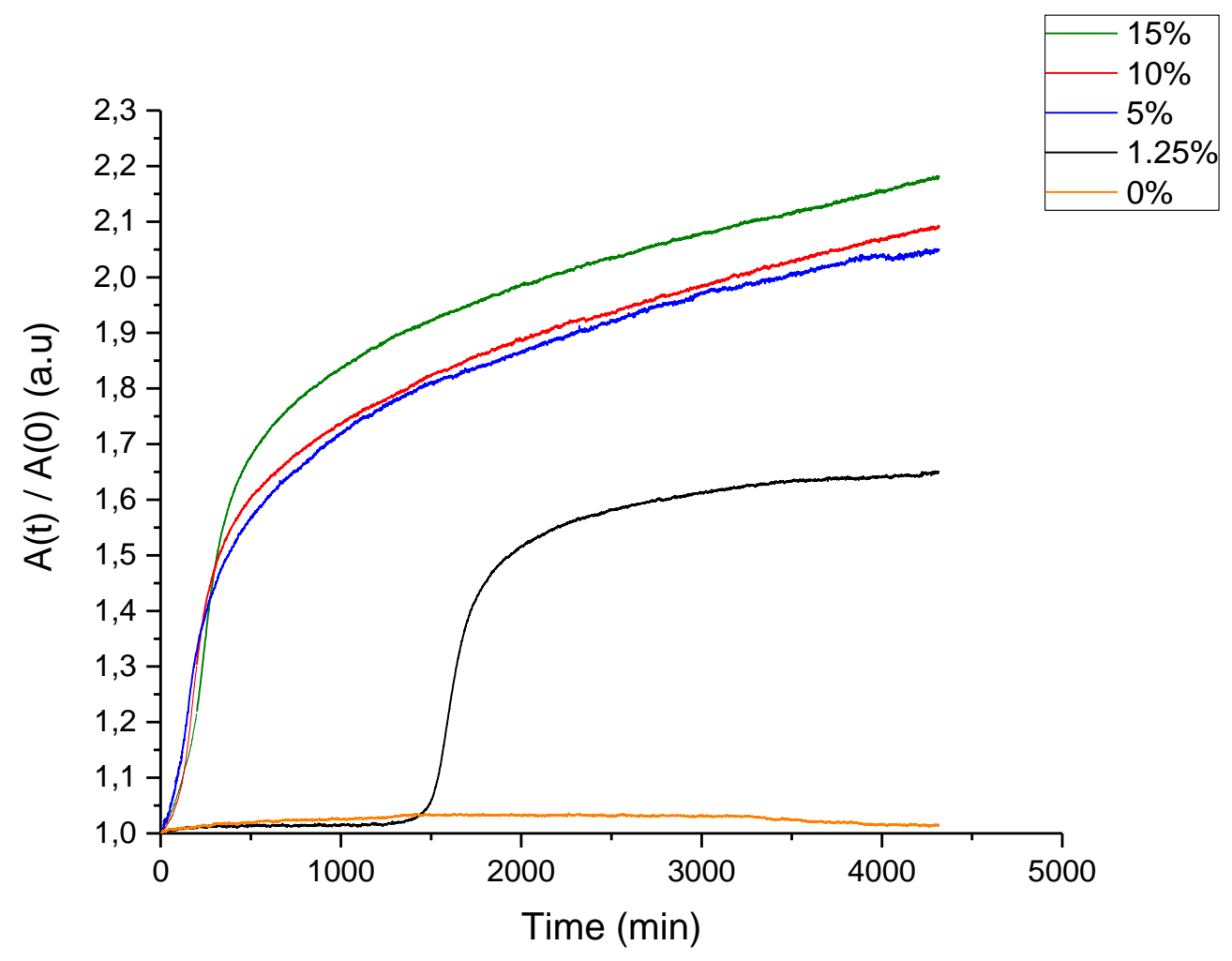

Figure 4: Evolution of normalized absorbance at $932 \mathrm{~cm}^{-1}$ during the first three days of curing for each A/S, obtained by FTIR in situ measurements. $A(0)$ is the absorbance value at time $t=0 \mathrm{~min}$

The continuous in situ acquisition of infrared spectra during the first 3 days of hydration allowed to measure the evolution with time of the absorbance of the $932 \mathrm{~cm}^{-1}$ band, related to C-A-S-H (Figure 4). The absorbance is normalized by its value at the beginning of the experiment. When slag is mix with free water $\left(\mathrm{Na}_{2} \mathrm{O}=0 \%\right)$, no evolution of the absorbance of the band at $932 \mathrm{~cm}^{-1}$ is observed. No C-A-S-H hydrates are detected during the first 3 days, which is consistent with the fact that slag hydration in water is very slow [3]. For an A/S ratio of $1.25 \%$, first hydrates precipitation is detected around $1500 \mathrm{~min}(25 \mathrm{~h})$. This result is consistent with individual measurements (Figure 3.a) and with the poor cohesion noted at 1 day (Figure 2.a). The absorbance increases then rapidly until $2500 \mathrm{~min}(42 \mathrm{~h})$ before slowing down until being almost constant at a relatively low level regarding to others formulations. One can note that during the first 24 hours, in situ spectra of $1.25 \%$ sample and of free water present a similar shape, with no possible identification of any characteristic band of anhydrous or hydrated slag (available in the supplementary material). Since the depth of penetration of the evanescent infrared wave used in ATR mode is estimated to approx. $5 \mu \mathrm{m}$ for those materials, it may only penetrates a thin water layer formed between slag grains and ATR crystal. The 
formation of this water layer indicates a poor solubility of slag grains in water and limited chemical interactions between slag and pure water. That could explain the low dissolution rate of slag in these conditions. This phenomenon is not observed with higher amount of activator. For an activator content above 5\%, hydrate formation starts in the very first minutes after mixing and can be separated into two main phases. At first, hydrate formation accelerates and quickly increases until $490 \mathrm{~min}(\approx 8 \mathrm{~h})$ for 5 and $10 \%$ of activator and $550 \mathrm{~min}(\approx 9 \mathrm{~h})$ for $15 \%$. Then in a second phase, the absorbance increase is smaller but still noted. Above $1.25 \%$, the absorbance evolution is quite the same whatever the A/S, showing that the hydrate formation is not related to it. Nonetheless the IR signal associated to hydrates formation increases slightly with activator ratio, especially above $10 \%$. It could be noted that these results are comparable with those obtained with in situ calorimetry with similar mix compositions $[17,49]$.

\subsection{Extent of Reaction}

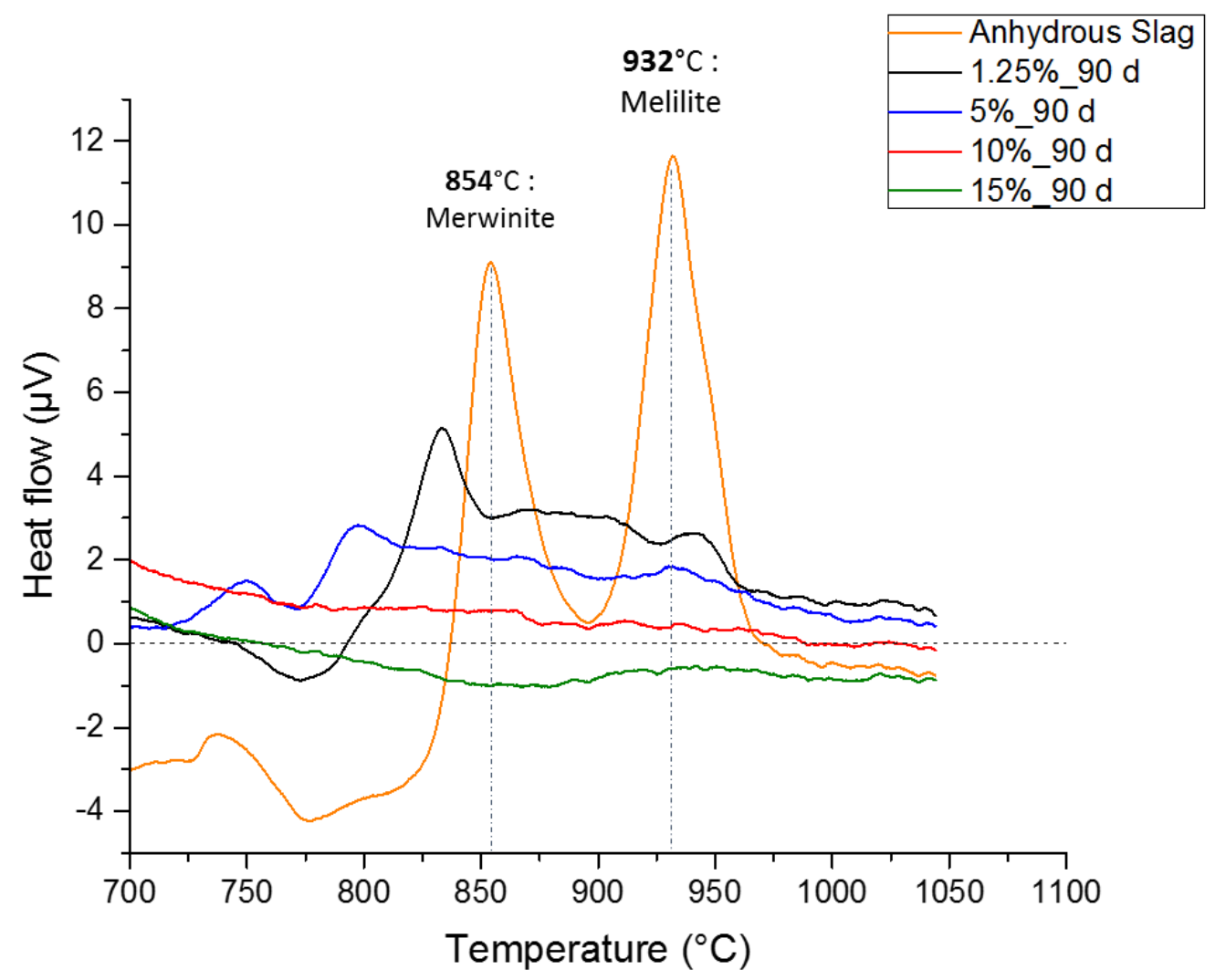

Figure 5: DTA curves of anhydrous slag and hydrated samples for each A/S after 90 days of curing between $700^{\circ} \mathrm{C}$ and $1100^{\circ} \mathrm{C}$ 
Extent of reaction of hydraulic materials such as OPC or slag can be qualitatively evaluated thanks to differential thermal analysis [28,61]. Indeed, as illustrated in Figure 5, anhydrous slag starts to crystallize above $700^{\circ} \mathrm{C}$ into a metastable phase, Merwinite $\left(\mathrm{Ca}_{3} \mathrm{Mg}(\mathrm{SiO})_{2}\right)$, and then to a more stable crystalline phase, Melilite $\left(\mathrm{Ca}_{2}(\mathrm{Mg}, \mathrm{Al})\left[(\mathrm{Al}, \mathrm{Si}) \mathrm{SiO}_{7}\right]\right)$ [28]. These crystallizations are clearly noted on the DTA curve of anhydrous slag by two exothermic peaks at $850^{\circ} \mathrm{C}$ and $930^{\circ} \mathrm{C}$ respectively [3]. Besides, the endothermic zone between $700^{\circ} \mathrm{C}$ and $830^{\circ} \mathrm{C}$ corresponds to the germination of slag before its crystallization [28]. Figure 5 also presents the DTA curves obtained for hydrated samples with different activator ratio after 90 days of curing. For the $1.25 \%$ sample, the slag germination phenomenon is still noted and the two crystallization's exothermic peaks are identifiable. Nonetheless, dissolution of slag grains is observable by the modification of both the germination endothermic zone and the shape of exothermic peaks, the latter being spread out on a larger range of temperature. This is related to a chemical and structural modification of amorphous phases. However, the presence of these exothermic peaks indicates that amorphous phases are still present in the sample, so that hydration is not fully achieved after 90 days. The shape of exothermic peaks are even more modified when the activator ratio increases to $5 \%$, even if the first transition peak is slightly visible at $800^{\circ} \mathrm{C}$. The extent of reaction can thus be considered as more advanced. When activator ratio excesses $10 \%$, no identifiable exothermic phenomena are identifiable, so that no more initial amorphous phases, specific of anhydrous slag, are present in the sample. The dissolution of initial grains can be considered as complete.

These interpretations are confirmed by FTIR results after 90 days of curing time (Figure 6). For both anhydrous slag and sample activated with $1.25 \%$ of sodium, carbonate phases specific of anhydrous state are identifiable between 1550 and $1400 \mathrm{~cm}^{-1}$ (Figure 6.b) and also at $875 \mathrm{~cm}^{-1}$. Besides, for this activated sample, characteristic bands of hydrated phases such as C-A-S-H at 932, 812 and $650 \mathrm{~cm}^{-1}$ are very weak (Figure 6.a). These observations confirm that, even after 90 days, hydration of the $1.25 \%$ sample is very low and dissolution of anhydrous phases are far from complete. For samples with activator content above 5\%, a change in the chemical environment of carbonates is observable as it is the case after 24 hours of curing (Figure 3), since the main band of carbonates is shifted from 1475 to $1385 \mathrm{~cm}^{-1}$, attributed to hydrated sodium carbonates. This evolution is also illustrated with the increase of the $\mathrm{C}-\mathrm{O}$ band at 710 $\mathrm{cm}^{-1}$. The main bands at 932,812 and $650 \mathrm{~cm}^{-1}$, corresponding to $\mathrm{Si}-\mathrm{O}-\mathrm{T}(\mathrm{T}=\mathrm{Si}$ or $\mathrm{T}=\mathrm{Al}$ ) bonds and mainly attributed to C-A-S-H phase, are also clearly visible. After 90 days, the differences between spectra are less obvious, meaning that the extent of reaction are closer whatever the 
content of activator is, especially for $10 \%$ and $15 \%$. Nonetheless, development of hydrotalcitelike phase at $890 \mathrm{~cm}^{-1}$ is only noted for an activator content above $10 \%$, and is more obvious when activator amount increases. It could be also indicated by the presence of the absorbance bands at $605 \mathrm{~cm}^{-1}$, attributed to $\mathrm{Al}-\mathrm{OH}$ or $\mathrm{Mg}-\mathrm{OH}$ translation frequencies [50], and at $710 \mathrm{~cm}^{-}$ ${ }^{1}$, attributed to carbonated species. Besides, it is worth noting that portlandite is only detectable at $3640 \mathrm{~cm}^{-1}$ for samples with 10 and $15 \%$ of activator ratio (Figure $6 . \mathrm{c}$ ).

(b)

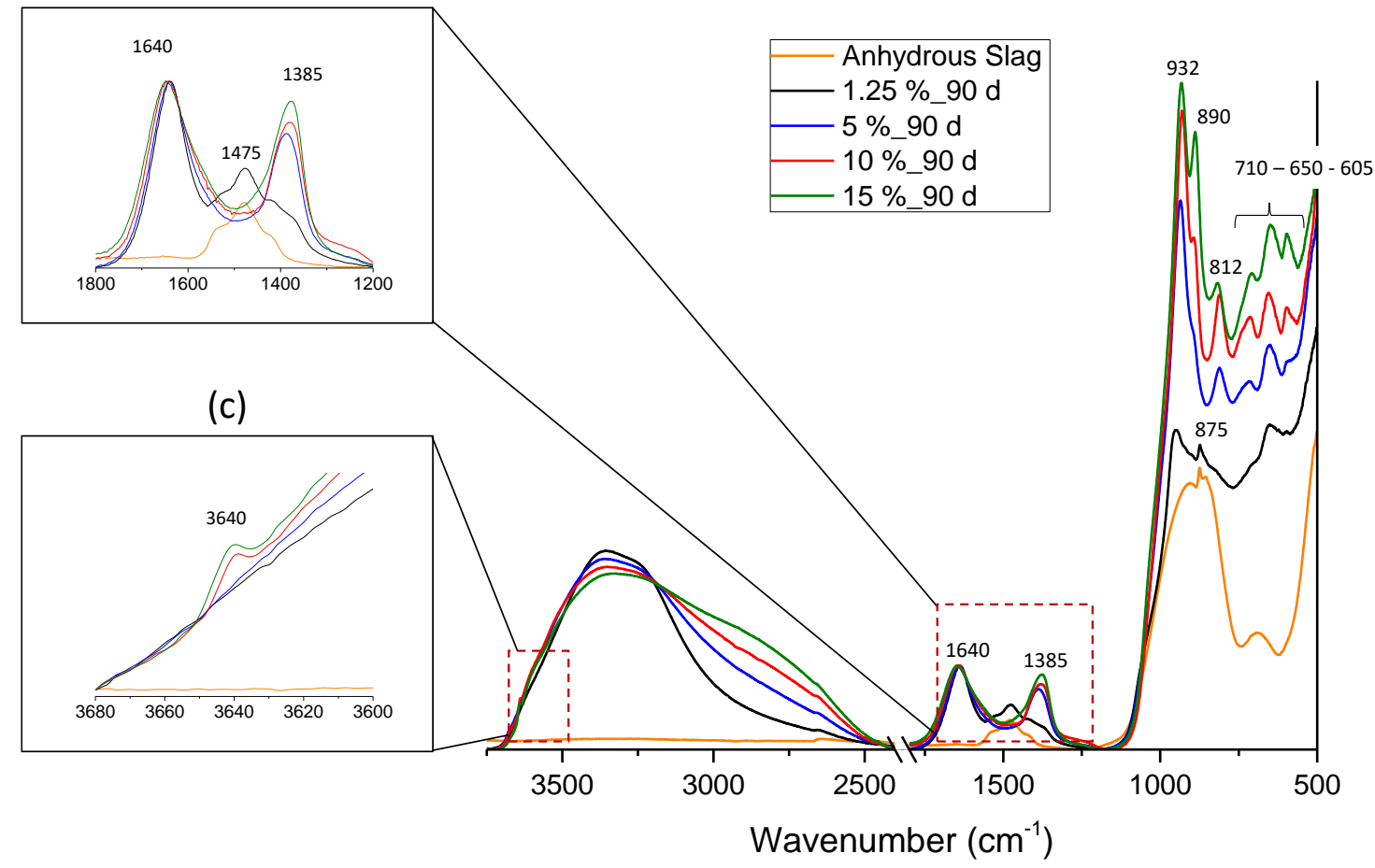

Figure 6: (a) FTIR spectra of anhydrous slag and hydrated samples for each A/S after 90 days of curing between 500 - 3800 $\mathrm{cm}^{-1}$, (b) zoom between $1200-1800 \mathrm{~cm}^{-1}$ and (c) zoom between $3600-3680 \mathrm{~cm}^{-1}$

\subsection{Phase identification}

Figure 7 presents XRD patterns obtained for anhydrous slag and each samples at 90 days. XRD data for anhydrous slag confirms its amorphous state, as noted by the broad dome between $25^{\circ}$ and $37.5^{\circ}$. The presence of vaterite, a calcium carbonate crystalline phase, is clearly visible at $27^{\circ}$ and confirm FTIR results previously presented (Figure 3). The sample with $1.25 \%$ of activator presents a broad dome that can be attributed to either the formation of a poor crystalline hydrates gel or the remaining of non-dissolved anhydrous slag. The latter hypothesis 
is preferred since it is consistent with DTA (Figure 5) or FTIR (Figure 6) results. C-A-S-H formation is noted with peaks at $29^{\circ}, 32^{\circ}, 44^{\circ}$ and $50^{\circ}$ [38,51,57,62-64]. The C-A-S-H peak at $32^{\circ}$ is less clearly visible for $1.25 \%$ of activator than for other formulations. It could be specific of less crystallized C-A-S-H or it could be an indication of a larger amount of Al uptake. In fact, C-A-S-H diffractograms may evolve with Al content integrated into C-A-S-H phase [65]. It has been shown that increasing $\mathrm{Al}$ content can slightly modify basal distances of C-A-S-H, especially above an $\mathrm{Al} / \mathrm{Si}$ ratio of 0.2 , as noted on XRD diffractograms by a reduction in intensity of the $32^{\circ}$ peak $[51,66]$. Al uptake seems thus favored for low activator content, that is to say when aluminum is not precipitated into more stable phases such as aluminate hydrate or hydrotalcite-like phases [11]. Indeed, hydrotalcite amount is very low for this formulation and almost undetectable. Vaterite is no longer clearly visible, assuming it has been at least partially dissolved during slag hydration.

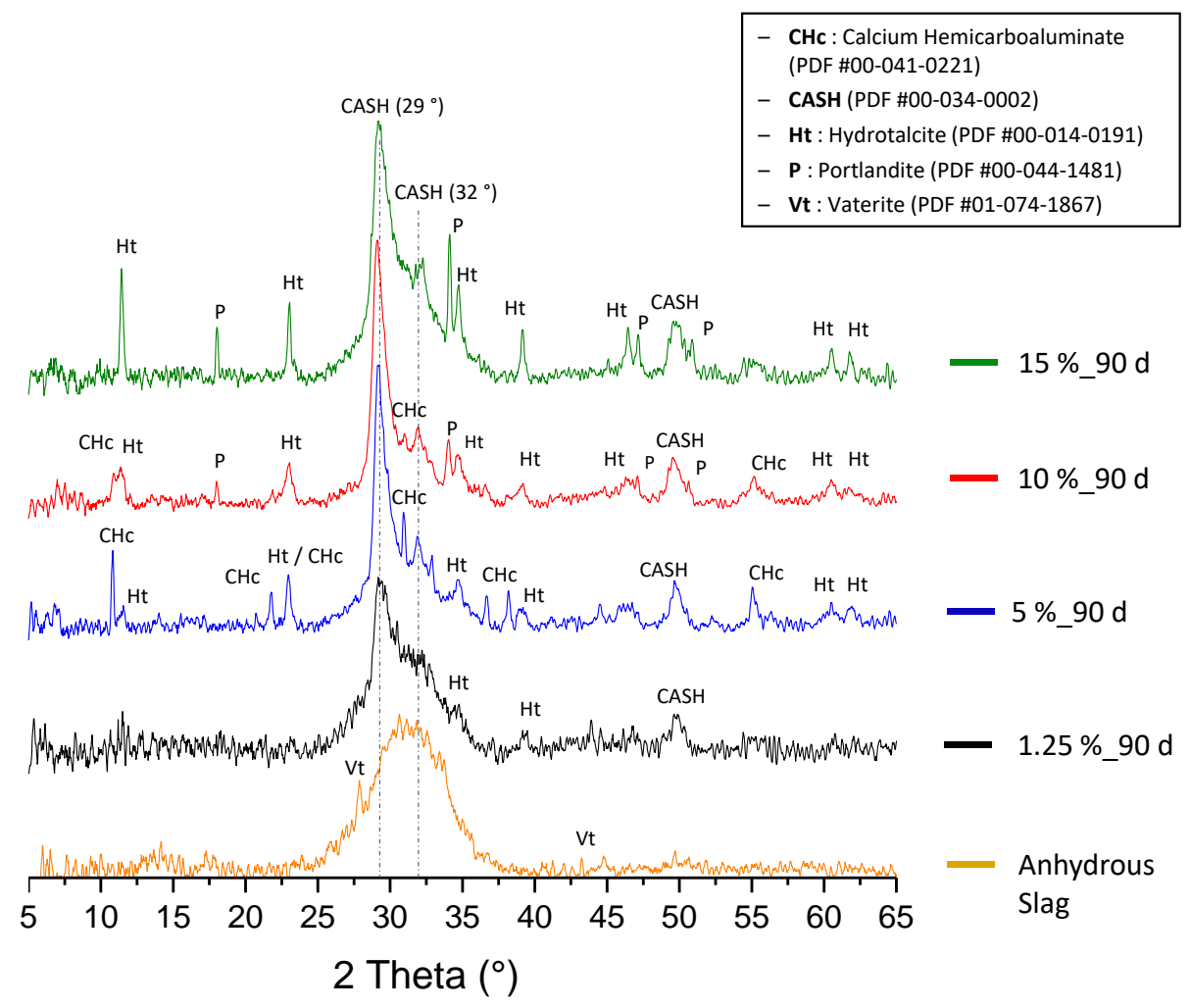

Figure 7: XRD patterns (Intensity (a.u.) versus 2 Theta $\left({ }^{\circ}\right)$ ) of anhydrous slag and hydrated samples for each A/S after 90 days of curing

The diffractogram obtained for the $5 \%$ sample presents the main peaks at $29^{\circ}, 32^{\circ}$ and $50^{\circ}$, confirming formation of C-A-S-H hydrates. The main difference with the $1.25 \%$ sample is the 
presence of calcium hemicarboaluminate hydrate $\left(\mathrm{CHc}-\left[\mathrm{Ca}_{4} \mathrm{Al}_{2}(\mathrm{OH})_{12}\right]\left[\left(\mathrm{CO}_{3}\right)_{0.5}(\mathrm{OH}) \cdot \mathrm{nH}_{2} \mathrm{O}\right]\right.$ [67], with a structure close to AFm-like phases: $\mathrm{Ca}_{2} \mathrm{Al}(\mathrm{OH})_{6} \cdot \mathrm{X} \cdot \mathrm{nH}_{2} \mathrm{O}$, where $\mathrm{X}$ can be a single or half a double charged anion [68]). The formation of this phase is correlated with the chemical change observed in the carbonates region of the FTIR spectra for 5\% (Figure 6). The formation of hydrtoalcite-like phase is poorly observable at this stage. With an increase of A/S up to 10\%, the peak of C-A-S-H is more pronounced and hydrotalcite-like becomes predominant over CHc. The formation of portlandite is clearly visible at $18^{\circ}$ and $34^{\circ}$. This observation confirms the FTIR results previously presented (Figure 6). For the sample with $15 \%$ of activator, the main phase is still C-A-S-H. The widening of a small dome between 30 and $32^{\circ}$ can be related to the formation of a poorly crystalline gel whose structure and chemical composition are slightly different from the main C-A-S-H phase and could be attributed to C-N-ASH phase. Hydrotalcite-like phase and Portlandite are more visible and well-defined than for the other formulations, meaning that the increase in sodium content favors the formation and the crystallinity of these phases.

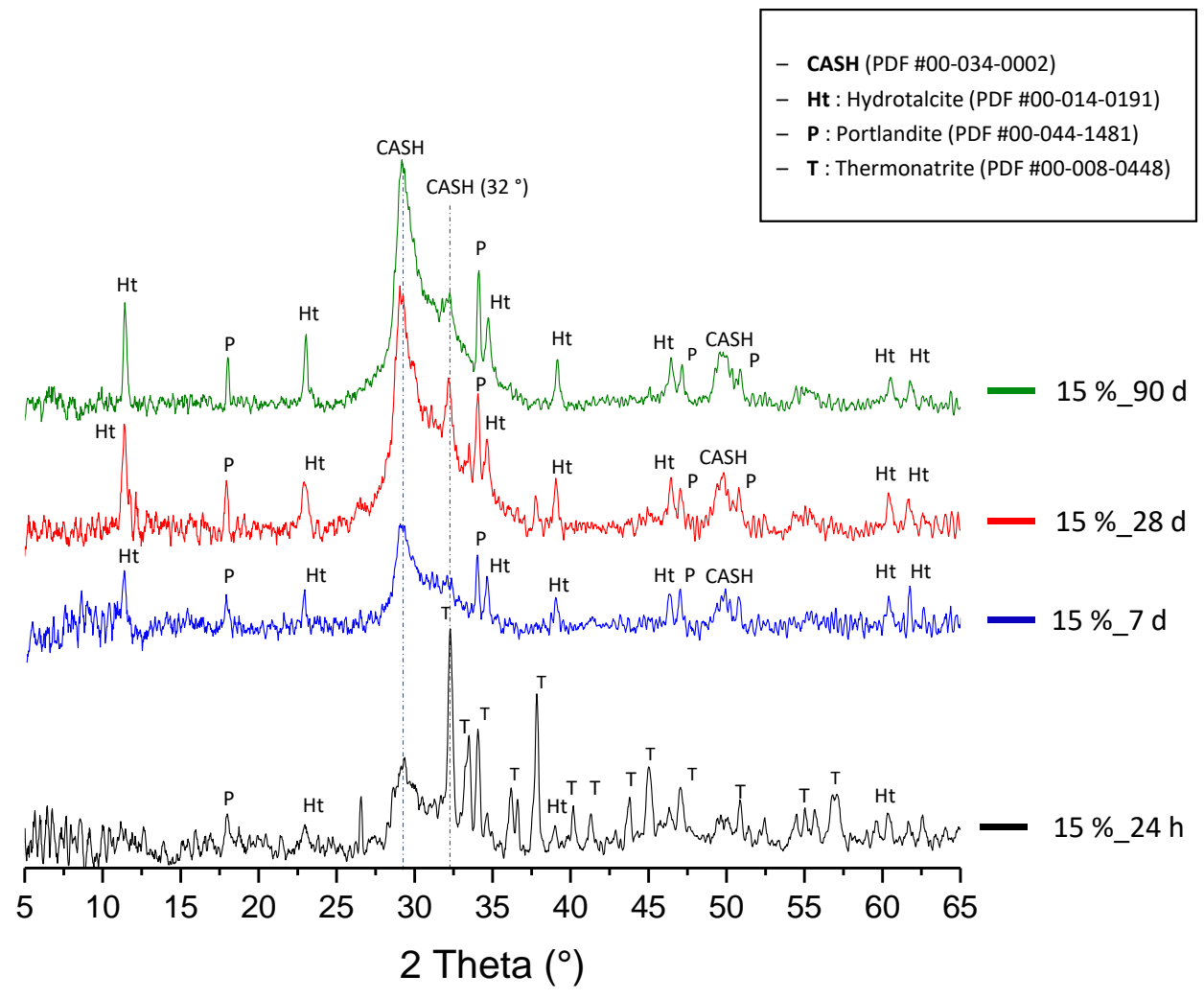


Evolution of phase formation with time is illustrated by comparing XRD patterns for a given sample at each curing time, as shown in Figure 8 for the 15\% sample. After 24 hours of curing, the amorphous dome of anhydrous slag is no longer visible, assuming that dissolution of initial grains is complete. The main phase detected is thermonatrite $\left(\mathrm{Na}_{2}\left(\mathrm{CO}_{3}\right) \cdot \mathrm{H}_{2} \mathrm{O}\right)$, a hydrated sodium carbonate. Formation of sodium carbonates reveals the presence of a large amount of free sodium available to react with carbon dioxide present in the ambient air that could be formed during sample grinding or during XRD acquisition. This phase has not been detected in other formulations, meaning that this excess of sodium at early age is noted when sodium hydroxide is used above $10 \%$ of slag mass. In these conditions sodium ions in excess may participate to slag dissolution but they are not integrated into stable phases, allowing their reaction with carbon dioxide of ambient air through the precipitation of sodium carbonates. The characteristic peak of C-A-S-H is obviously present at $29^{\circ}$. A small amount of hydrotalcite-like phase and portlandite are also detectable at this age. After 7 days of curing, sodium carbonates are no longer detected, assuming that all initial excess of sodium takes part into hydrated phase formation, so that they are no more available to precipitate into carbonated phases. Portlandite and hydrotalcite-like phase formation increase. XRD patterns for 28 and 90 days are similar and no notable evolution is detectable after 28 days. The hydrated phases formed are then mainly C-A-S-H, portlandite and hydrotalcite-like phase.

Phase identification can be completed and confirmed by thermogravimetric analysis (TGA). Derivative weight loss (dTG) for anhydrous slag and hydrated samples after 90 days (Figure 9.a) present several characteristic peaks in the range of $50^{\circ} \mathrm{C}-1100^{\circ} \mathrm{C}$. The main one is attributed to the loss of bound water of C-A-S-H phase [31,69-71], its temperature increases with initial activator content as follow: $142,155,157$ and $170^{\circ} \mathrm{C}$ for $1.25,5,10$, and $15 \%$ of activator respectively. 
a)

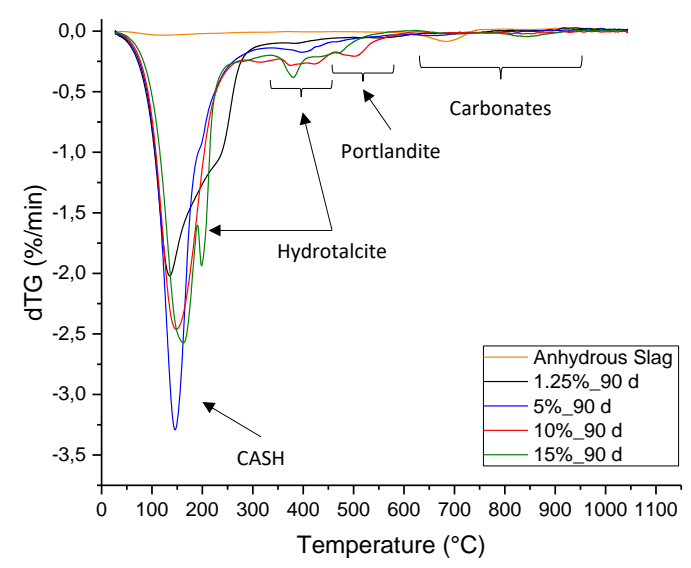

b)

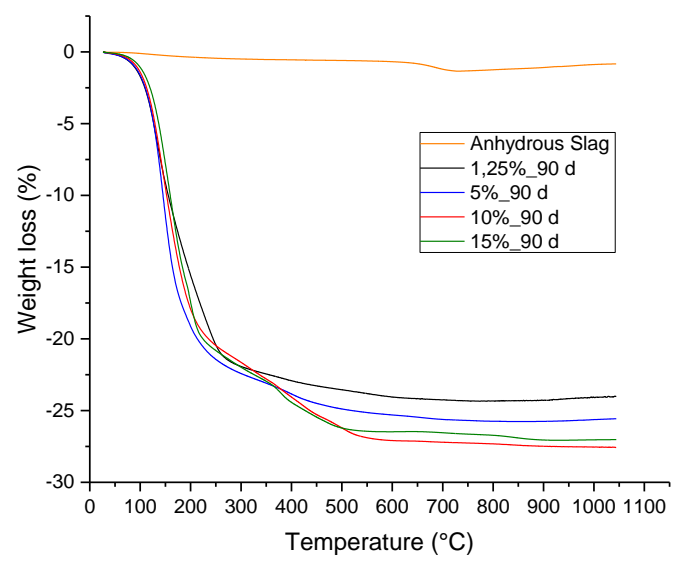

Figure 9: (a) Derivative weight loss (dTG) and (b) weight loss of anhydrous slag and hydrated samples at 90 days for each A/S

This temperature shift is related to the enthalpy of evaporation of water in the main hydrated phases, so that the more the temperature increases, the more the water molecules are bound into the structure. A stronger bound water can be related either to a more compact structure, or to an increase in alkali uptake into the structure that can bind more strongly a larger number of water molecules. The shoulder observed for $1.25 \%$ sample at $250^{\circ} \mathrm{C}$ can be related to the formation of better crystallized calcium aluminosilicate hydrates containing a large amount of aluminum, in accordance with XRD measurements (Figure 7). It should be noticed that this reorganization of the C-S-H appears between 28 and 90 days. The shoulder at $200^{\circ} \mathrm{C}$ and the peak at $385^{\circ} \mathrm{C}$ for the $15 \%$ sample, are attributed to water loss and dehydroxylation of hydrotalcite-like phase respectively [30,31,38,69,71,72]. Weight loss between 450 and $650^{\circ} \mathrm{C}$ is related to dehydroxylation of portlandite [69] and is only observed for 10 and $15 \%$ sample, supporting that this phase is only formed for high activator ratios. The weight loss observable at $680^{\circ} \mathrm{C}$ for anhydrous slag is attributed to the loss of $\mathrm{CO}_{2}$ from the vaterite phase. This loss is no more observable after 90 days of curing whatever the initial activator content is. This supports that vaterite has been at least partially dissolved at this curing time, as noted with XRD results (Figure 7). A slight weight loss at $850^{\circ} \mathrm{C}$ noted for initial activator content superior to $10 \%$ is attributed to the loss of $\mathrm{CO}_{2}$ from the hydrotalcite-like phase [14] (Figure 9.b).

Figure 10 shows SEM images of fracture surfaces of 1.25 and $15 \%$ samples after 24 hours, 7 and 28 days of curing respectively. After 24 hours, slag grains are clearly visible for both formulation but present different surface morphologies. For $1.25 \%$ sample, grains are angular, 
present smooth surfaces and are individually dispersed. They show a morphology very close to those of anhydrous grains [58]. This observation is coherent with the fact that hydration has not already occurred after 24 hours with $1.25 \%$ of activator. Conversely, for the $15 \%$ sample, grain's surfaces show large pits, assumed to be centered on points of favored attack and dissolution. Besides, hydrates precipitation, such as C-A-S-H phases, are visible on the surfaces. Hydrates growth allow connections between grains which start to form a continuous structure so that macroscopic cohesion is achieved. 

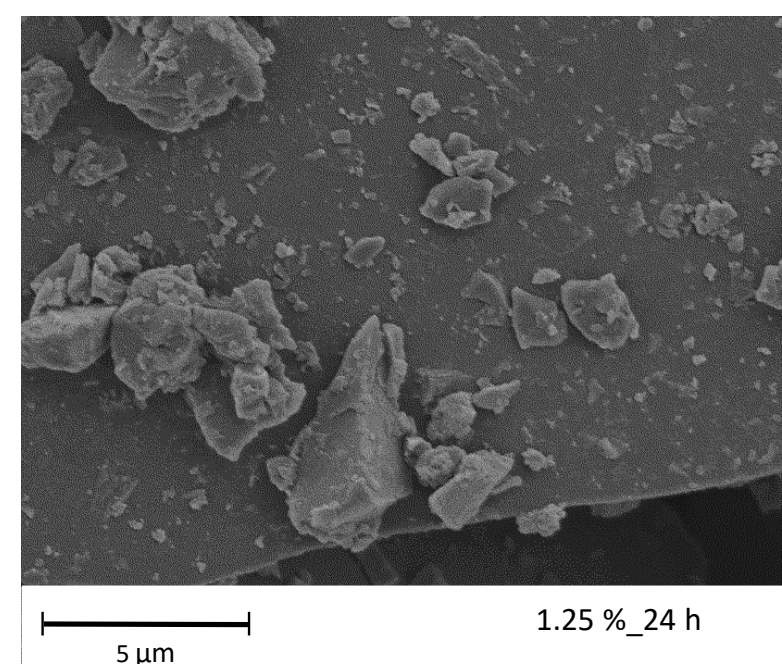

$5 \mu \mathrm{m}$

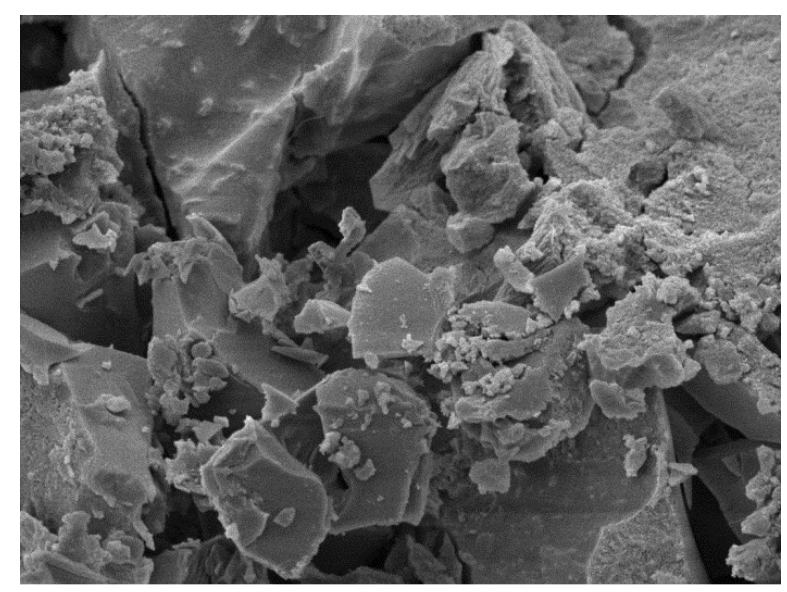

$\longmapsto 5 \mu \mathrm{m}$

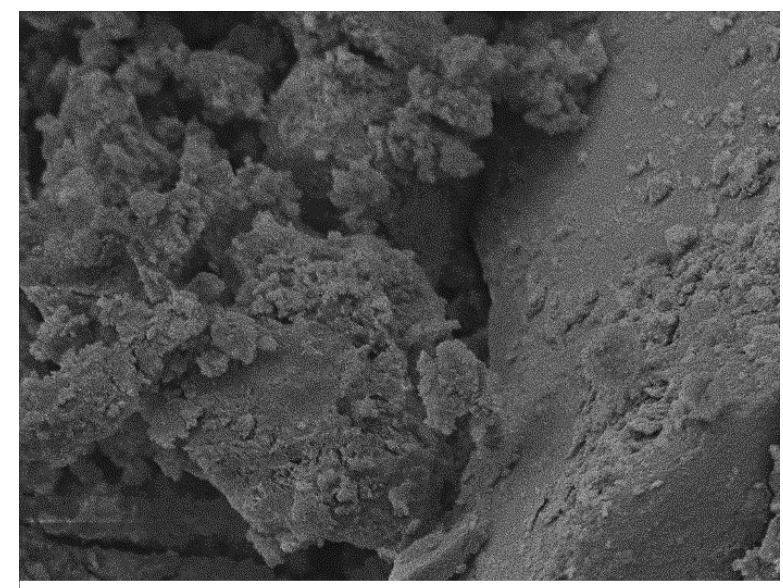

$5 \mu \mathrm{m}$
$1.25 \% \_7 d$

$1.25 \% \_28 d$

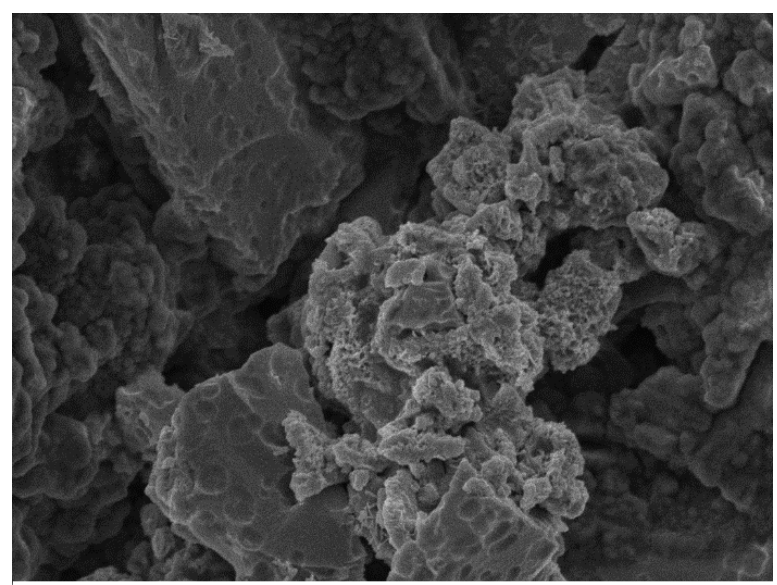

$15 \% \_24 \mathrm{~h}$

$5 \mu \mathrm{m}$

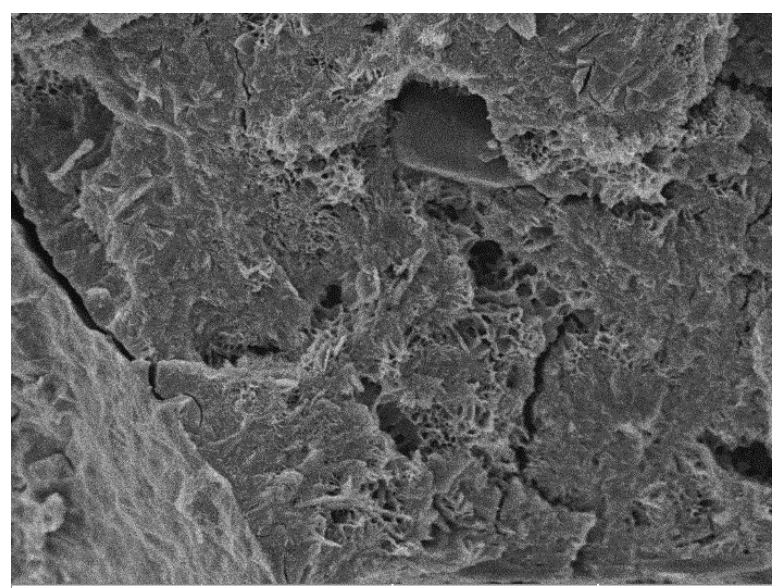

$15 \%$ \% d

$5 \mu \mathrm{m}$

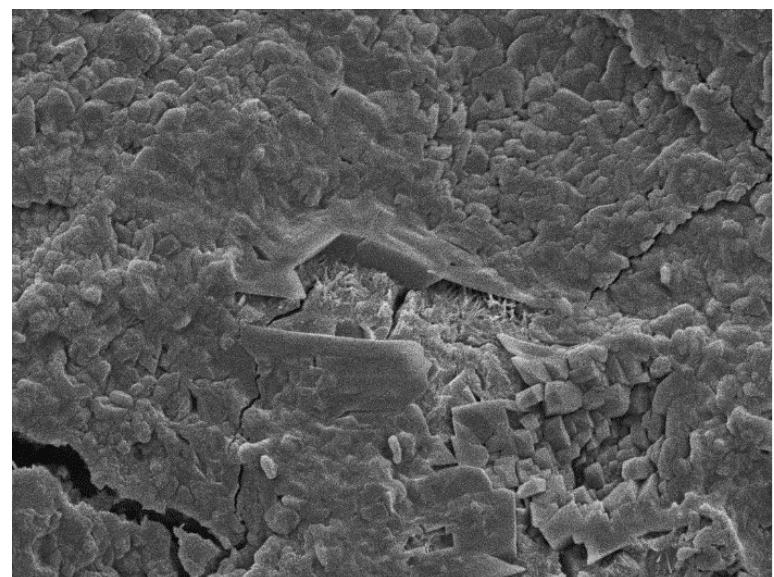

$5 \mu \mathrm{m}$
$15 \% \_28 d$

Figure 10: SEM backscattered electron images of fracture surfaces of samples with 1.25 (left) and 15\% (right) of activator after 24 hours (top line), 7 days (middle line) and 28 days (bottom line) of curing time

After 7 days of curing, slag grains are still visible for $1.25 \%$ of activator but they present signs of activation with a less angular morphology and with precipitated hydrates on their surface. 
First signs of activation are noted but in a relatively limited amount. With $15 \%$ of activator, slag grains are no more identifiable and the sample shows a relatively dense gel of honeycomblike type II C-A-S-H phase, with hydrotalcite-like or portlandite platelets [73]. These observations are in agreement with a well hydrated paste containing the hydrates identified previously. After 28 days, hydration of slag grains is not complete for $1.25 \%$ of activator, since grains are still identifiable. Nonetheless, their surface present a larger amount of hydrates, related to a better extent of reaction. Alkaline attack seems to be preferential on smaller grains and angular edges. These topologies presenting smaller radius of curvature that favors dissolution/precipitation phenomena [74,75]. On the other hand, the $15 \%$ sample presents a dense and packed structure formed by C-A-S-H phases coated by a dense gel.

EDX analyses were performed on the sample with $15 \%$ of activator and after 90 days of curing (Figure 11). The gel is composed of two main phases nested one into the other (Figure 11.a). The shape of the core phase allows to consider it as the section of a fully hydrated slag grain surrounded by a second hydrated phase. A line analysis was performed to compare the atomic distribution between the core and the shell phases (Figure 11.b). The local concentrations are different inside and outside the volume of the initial grain, leading to the formation of inner products (Ip) and outer products (Op), as already mentioned by Richardson [16,76]. Inner products show a higher concentration in calcium and silicon and a lower concentration of sodium with $\mathrm{Ca} / \mathrm{Na}$ atomic ratio of $13.67 \pm 4.38$, and $\mathrm{Ca} / \mathrm{Si}$ ratio of $1.10 \pm 0.24$ as compared to outer products which values are $2.08 \pm 0.87$ and $1.24 \pm 0.41$ respectively. The measured $\mathrm{Ca} / \mathrm{Si}$ ratios are consistent with those reported in literature [14,49]. The concentration gradient clearly observed here has also been suggested in previous studies [27]. The atomic ratios between Op and Ip phases are presented in Table 3. They are significantly inferior to 1 for calcium, aluminum and silicon. These species, initially present in the slag grain, are more present in Ip than in Op, suggesting a low rate of diffusion outside of the grain. Conversely, sodium ratio is largely superior to 1 , supporting that a large proportion of sodium has not diffused into the grain. This analysis underlines the weak diffusion of sodium into the initial slag grains, already pointed out in other studies $[17,77]$. Therefore, with a high initial activator content, sodium is mainly integrated into an outer hydrated gel, which is commonly described as C-N-ASH gel $[13,23,57,78]$. It could be noted that $\mathrm{Ca} / \mathrm{Si}$ atomic ratio of anhydrous slag is closed to that of the Op phase (1.27 - Table 1) which is consistent with a relatively congruent dissolution of calcium and silicon in the vicinity of the grain. 
a)

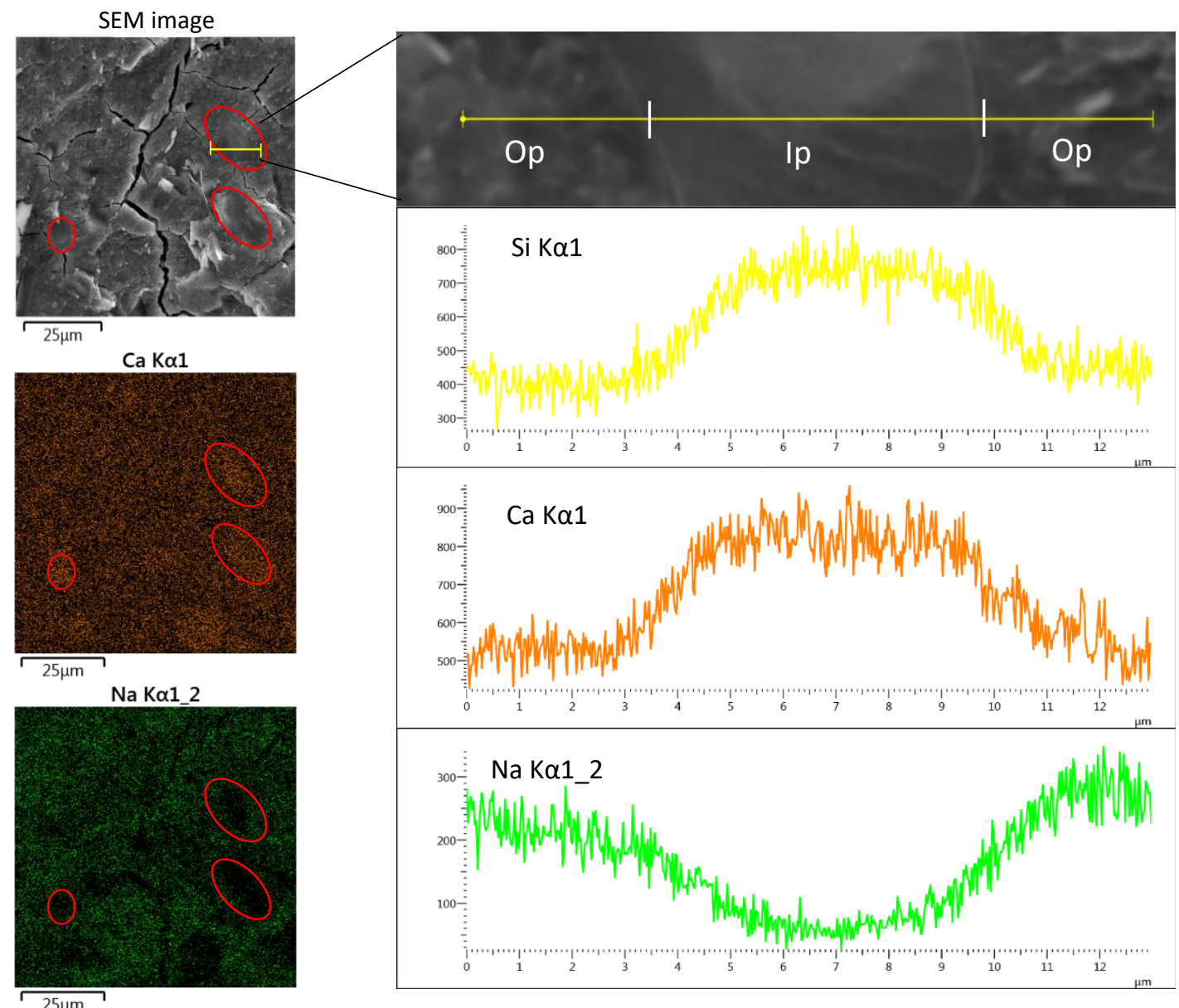

Figure 11: (a) SEM image and elemental maps - red circles refer to grain's shape and yellow line to the line analysis performed - and (b) EDX elemental line analysis, for sample with $15 \%$ of activator after 90 days of curing

The kinetic of hydration can be considered fast for the $15 \%$ sample, since hydrates formation begins during the first few minutes after mixing (Figure 4). Under these conditions, hardening of the paste is too fast to allow a good diffusion of dissolved species between the slag grain and the interstitial solution, leading to different compositions for Ip and Op. Besides, locally different compositions have been pointed out by some authors in relation to the kinetic of the reaction, the slower the reaction of hydration, the higher the level of diffusion throughout the gel [31]. 
Table 3: Atomic ratio (from EDX analysis) between inner (Ip) and outer $(O p)$ products for the sample with $15 \%$ of activator after 90 days (see Figure 10)

\begin{tabular}{ccccc}
\hline & $\mathbf{C a}$ & $\mathbf{S i}$ & $\mathbf{A l}$ & $\mathbf{N a}$ \\
\hline $\mathbf{O p} / \mathbf{I p}$ & & & & \\
(atomic ratio) & $0.65 \pm 0.14$ & $0.58 \pm 0.19$ & $0.49 \pm 0.17$ & $4.33 \pm 1.39$ \\
\hline
\end{tabular}

\section{Discussion}

Thanks to the use of complementary characterization techniques, it is possible to give a quantitative estimation of hydrates fraction with time for slag formulations at different $\mathrm{A} / \mathrm{S}$ ratios (see Figure 12). The phases considered are those identified by XRD, FTIR, and TGA analyses. Their amount are evaluated thanks to thermogravimetric measurements according to temperature range assignation described in section 3.4 (the curves of weight loss are available in the supplementary material). Figure 12 presents the proportion of the total weight loss assigned to each hydrated phase, including physisorbed water. This representation synthesizes the results previously presented (Figure 9) 

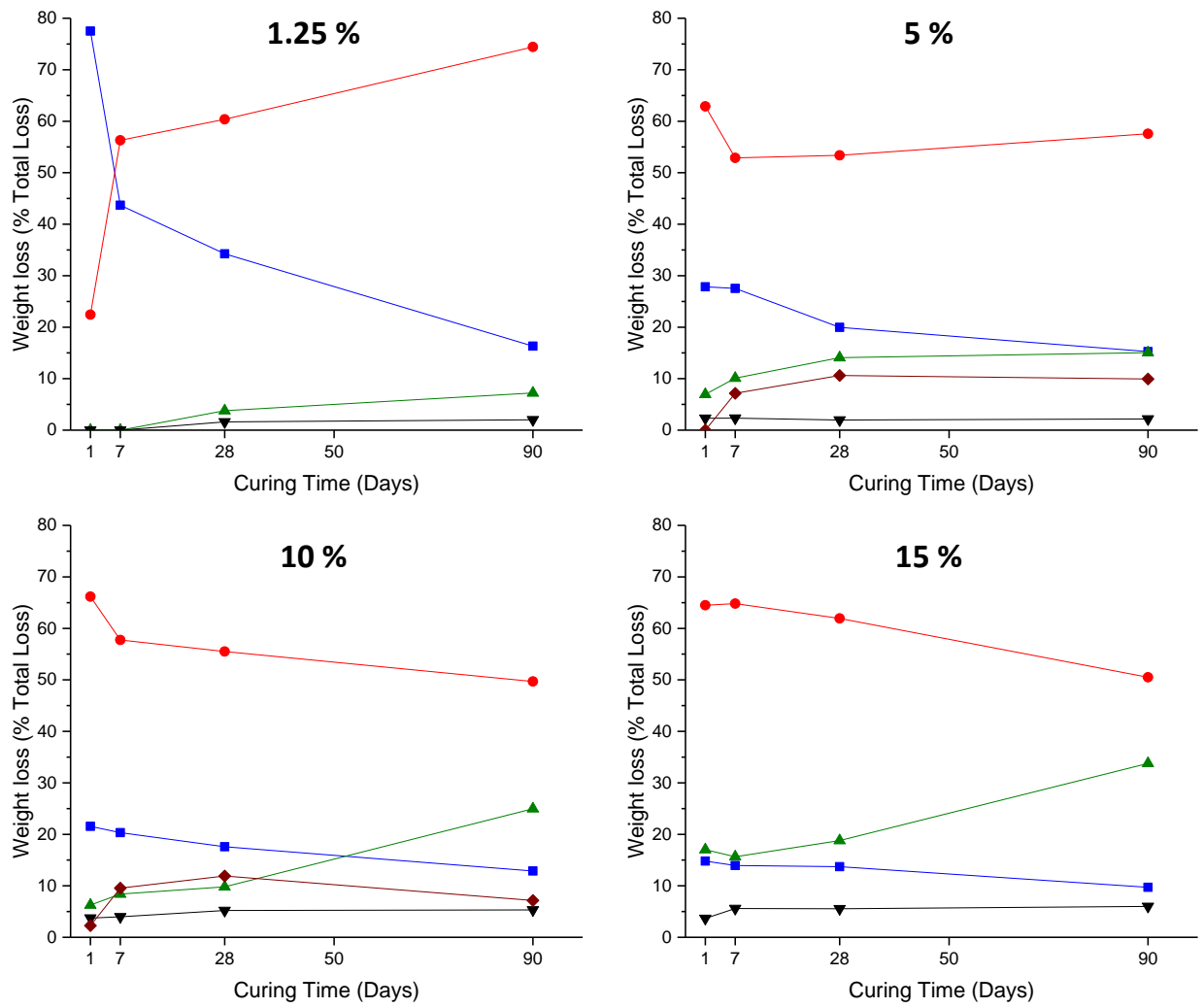

Figure 12: Evolution with time of the weight loss proportion assigned to hydrated phases for each A/S

With only $1.25 \%$ of initial activator content, experimental data show that the dissolution is not completely achieved even after 90 days. The presence of initial glass structure and vaterite, both specific of the anhydrous state of the grains, is still noted by DTA (Figure 5) and FTIR (Figure 6 ) respectively. Kinetic of hydration is slow, considering the important amount of free water and the low content of hydrates such as calcium aluminum silicate hydrates (C-A-S-H) after 24 hours. Absence of significant amount of calcium hemicarbonate $(\mathrm{CHc})$ or hydrotalcite-like phase is also an indicator of the low level of reaction. Mechanical properties are then very low and reach a maximum at 28 days with little evolution afterwards (Figure 2.a). An A/S ratio of $1.25 \%$ (equivalent to a $1 \mathrm{M}$ activating solution) is therefore not sufficient for a good hydration of the tested GBFS. Considering that the activating solution for this material has an initial $\mathrm{pH}$ value superior to 13 and close to other formulations (Table 2), this underlines the importance of cationic content for slag's activation, so that a high initial $\mathrm{pH}$ value is not sufficient to ensure a good activation, especially at early age. Besides, it is worth noting that increasing sodium concentration in the activating solution increases its ionic strength, which enables a better deflocculation of anhydrous slag grains. A good dispersion of slag grains is critical to achieve 
a better dissolution and a better extent of hydration. This deflocculating effect is easily observable by the increase of fluidity during mixing when activator content increases, even though water content is kept constant.

Above $5 \%$ of activator, no more anhydrous calcium carbonates are detected regardless of the curing time. Hydration starts quickly, with compressive strength above $10 \mathrm{MPa}$ at 24 hours (Figure 2 and Figure 4). This activator content leads to the formation of C-A-S-H and CHc in different proportions regarding curing time. Increase of $\mathrm{CHc}$ amount can be related to a better dissolution of carbonate phases with time and to an increase of calcium and carbonates ions available, and also to a favored precipitation of aluminum in $\mathrm{CHc}$ than in $\mathrm{C}-\mathrm{A}-\mathrm{S}-\mathrm{H}$ phases with ageing. The better dissolution of anhydrous slag, observable by DTA (Figure 5), leads to better mechanical properties (see Figure 2.a) thanks to a more complete hydration process as compared to $1.25 \%$.

For 10 and $15 \%$ of activator, in addition to the main C-A-S-H phase, portlandite and hydrotalcite-like are formed since the first day of hydration. The precipitation of portlandite for high activator content is mainly due to the common ion effect of $\mathrm{NaOH}$ which drastically reduces its solubility by several order of magnitude [79]. Incorporation of sodium into a C-NASH phase, partially instead of calcium interlayer counter ions, can also yields to higher amount of portlandite precipitation [59,80]. Conversely precipitation of portlandite consumes calcium released by slag dissolution and enhances alkali substitution by reducing calcium content integrated in C-A-S-H [59]. Alkali uptake in C-N-ASH phase instead of calcium can also favor precipitation of calcium-aluminum hydrates such as hydrotalcite-like or CHc. Nonetheless, when sodium hydroxide content is sufficient, hydrotalcite-like phases seem to be preferentially formed than $\mathrm{CHc}$ whose content decreases with time when activator content is superior to $10 \%$. The higher the initial sodium content, the higher the alkali substitution and the formation of C$\mathrm{N}$-ASH phase $[57,59,78,81,82]$ occurs. The precipitation of portlandite is also associated to a $\mathrm{pH}$ value of the interstitial solution above 12.5, corresponding to the dissolution equilibrium $\mathrm{pH}$ of this phase. For an activator content superior to $10 \%$, the $\mathrm{pH}$ value superior to 12.5 over time is partially responsible for the better extent of hydration observed on these samples. Besides, increasing sodium hydroxide content increases ionic strength and conductivity of the activating solution, which enhances slag grains dispersion and dissolution and allows a faster hydration.

Finally, with $15 \%$ of activator, the initial excess of free sodium is illustrated by the presence of hydrated sodium carbonate, such as thermonatrite, whose amount decreases rapidly with time after the first 24 hours. Then, sodium uptake into stable phases is mainly achieved after 7 days 
of curing. The higher sodium content leads also to a better stability of portlandite and C-A-S$\mathrm{H}$, and to a higher fraction of hydrotalcite-like phase. These observations and the large amount of hydrotalcite-like phase formed, are signs of a better hydration of slag grains and an increase in long-term mechanical performances.

At early age (in the first $24 \mathrm{~h}$ ) hydrated phases compositions are comparable for all A/S ratios superior or equal to $5 \%$, the amount of hydrotalcite-like phases is low and the kinetics of formation of C-A-S-H are similar (Figure 4). At this curing time, it is assumed that the amount of hydrotalcite-like phase is not sufficient to have an impact on mechanical results. Besides, the formation of portlandite does not result in an increase of the mechanical properties. Finally, presence of sodium carbonates in the $15 \%$ sample could be detrimental for mechanical performances. It results in equivalent mechanical properties for all $\mathrm{A} / \mathrm{S}$ ratios superior or equal to $5 \%$ (Figure 2), so that above 5\% the initial activator content has a little influence on slag's hydration at early age.

However, at later ages (after 28 days), hydrated phase compositions depend on the initial activator content. Especially, the amount and kinetic of hydrotalcite-like phase formed are correlated to an increase in mechanical performances. Therefore, initial activator content has a great influence on slag's hydration at later ages.

\section{Conclusion}

This work enabled to identify the hydrated phases formed with a large range of sodium hydroxide activating solution and highlighted influence of the activator content. The extent of reaction, the nature of hydrates formed, their kinetics of formation and their stability with time are affected by the initial activator to slag ratio, more than by the initial $\mathrm{pH}$ value of the activating solution when this one is superior to 13 . These observations can be explained by an increase of the ionic strength of the solution and an increase of the cationic network modifiers amount, sodium in this case. The higher amount of sodium allows to maintain a high $\mathrm{pH}$ value (> 12.5) for longer period of time, which is critical for slag's dissolution. Hence, the highest amount of activator leads to the highest mechanical properties after 90 days. Although $1.25 \%$ of slag weight (i.e., $1 \mathrm{M}$ activating solution) are largely used and studied for slag activation, it turned out to be insufficient for a complete hydration of slag grains, especially at early age. However, for an activator content superior to $10 \%$ (i.e., $8 \mathrm{M}$ solution), portlandite and hydrotalcite-like formation are favored and the latter is correlated to higher long-term 
mechanical performances. Portlandite precipitation, mainly attributed to the common ion effect due to high concentrations of sodium hydroxide, underlines the fact that initial activator content both plays a role in slag's dissolution and in hydrates' precipitation and composition. When the activator content reaches $15 \%$ of slag weight (i.e., $12 \mathrm{M}$ solution), sodium is considered in excess at early age but is incorporated into a C-N-ASH phase over time. Nonetheless, it should be kept in mind all the other parameters influencing slag hydration such as: slag chemistry and granulometry, nature of activator used, mixing and curing protocols and especially water content. Besides the durability of these materials should be further investigated and, among others, the stability of sodium which could be release during aging, especially when large amount of sodium hydroxide are used for activation. Finally, these results are of interest for the formulation of earth-based materials using alkali-activated slag binders by predicting hydrated phases formed during slag activation depending on the effective alkaline conditions. 


\section{References}

[1] F. Pacheco-Torgal, Z. Abdollahnejad, A.F. Camões, M. Jamshidi, Y. Ding, Durability of alkali-activated binders: A clear advantage over Portland cement or an unproven issue?, (2012). https://doi.org/10.1016/j.conbuildmat.2011.12.017.

[2] R. Maddalena, J.J. Roberts, A. Hamilton, Can Portland cement be replaced by lowcarbon alternative materials? A study on the thermal properties and carbon emissions of innovative cements, J. Clean. Prod. $186 \quad$ (2018) 933-942. https://doi.org/10.1016/j.jclepro.2018.02.138.

[3] J. Alexandre, J.-L. Sebileau, Le Laitier de Haut Fourneau, C.T.P.L., Paris, France, 1988.

[4] P. Sargent, The development of alkali-activated mixtures for soil stabilisation, in: F. Pacheco-Torgal, J.A. Labrincha, C. Leonelli, A. Palomo, P. Chindaprasirt (Eds.), Handb. Alkali-Activated Cem. Mortars Concr., Woodhead Publishing Limited, 2015: pp. 555604.

[5] A. Wilkinson, A. Haque, J. Kodikara, Stabilisation of clayey soils with industrial byproducts: Part B, Proc. Inst. Civ. Eng. Gr. Improv. 163 (2010) 165-172. https://doi.org/10.1680/grim.2010.163.3.165.

[6] V.R. Ouhadi, R.N. Yong, M. Amiri, M.H. Ouhadi, Pozzolanic consolidation of stabilized soft clays, Appl. Clay Sci. $95 \quad$ (2014) 111-118. https://doi.org/10.1016/j.clay.2014.03.020.

[7] S. Kang, S.-A. Bak, K. Kim, M. Song, Properties of ion leaching of alkali-activated blast furnace slag at early hydration, Adv. Cem. Res. 28 (2016) 151-157. https://doi.org/10.1680/jadcr.15.00073.

[8] A. Gruskovnjak, Hydration mechanisms of activated blast furnace slag, Berne, Suisse, 2006.

https://www.dora.lib4ri.ch/empa/islandora/object/empa\%3A12253/datastream/PDF/vie w (accessed May 13, 2019).

[9] R. Dron, Mécanisme de la prise du laitier granulé sous activation alcaline, Laboratoire des Ponts et Chaussées. Ministère de l'équipement, 1974.

[10] A. Fernández-Jiménez, F. Puertas, Effect of activator mix on the hydration and strength behaviour of alkali-activated slag cements, Adv. Cem. Res. 15 (2003) 129-136.

[11] K. Gong, C.E. White, Impact of chemical variability of ground granulated blast-furnace slag on the phase formation in alkali-activated slag pastes, Cem. Concr. Res. 89 (2016) 310-319. https://doi.org/10.1016/j.cemconres.2016.09.003.

[12] S. Wang, X. Pu, K.L. Scrivener, P.L. Pratt, Alkali-activated slag cement and concrete : a review of properties and problems, (1995) 93-102.

[13] R.J. Myers, B. Lothenbach, S.A. Bernal, J.L. Provis, Thermodynamic modelling of alkali-activated slag cements, Appl. Geochemistry. 61 (2015) 233-247.

[14] M. Ben Haha, B. Lothenbach, G. Le Saout, F. Winnefeld, Influence of slag chemistry on the hydration of alkali-activated blast-furnace slag — Part I: Effect of $\mathrm{MgO}$, Cem. Concr. Res. 41 (2011) 955-963.

[15] M. Ben Haha, B. Lothenbach, G. Le Saout, F. Winnefeld, Influence of slag chemistry on the hydration of alkali-activated blast-furnace slag — Part II: Effect of Al2O3, Cem. Concr. Res. 42 (2012) 74-83.

[16] I.G. Richardson, A.R. Brough, G.W. Groves, C.M. Dobson, The characterization of hardened alkali-activated blast-furnace slag pastes and the nature of the calcium silicate hydrate (C-S-H) phase, Cem. Concr. Res. 24 (1994) 813-829. https://ac-els-cdncom.docelec.insa-lyon.fr/0008884694900027/1-s2.0-0008884694900027-

main.pdf?_tid=6cde6942-db49-11e7-8e83-

00000aab0f02\&acdnat=1512649586_7ec43fc1da397ba1f896db210607b252 (accessed 
December 7, 2017).

[17] B.S. Gebregziabiher, R. Thomas, S. Peethamparan, Very early-age reaction kinetics and microstructural development in alkali-activated slag, Cem. Concr. Compos. (2015). https://doi.org/10.1016/j.cemconcomp.2014.09.001.

[18] A.M. Rashad, Y. Bai, P.A.M. Basheer, N.B. Milestone, N.C. Collier, Hydration and properties of sodium sulfate activated slag, Cem. Concr. Compos. (2013). https://doi.org/10.1016/j.cemconcomp.2012.12.010.

[19] S.-D. Wang, K.L. Scrivener, P.L. Pratt, Factors Affecting the Strength of AlkaliActivated Slag, Cem. Concr. Res. 24 (1994) 1033-1043. https://api-istexfr.docelec.insa-

lyon.fr/document/FFA64EE047DDAE2185FB5D20293A7165B4BB547B/fulltext/pdf? auth=ip,fede\&sid=ebsco,istex-view (accessed December 20, 2018).

[20] A. Fernández-Jiménez, J.G. Palomo, F. Puertas, Alkali-activated slag mortars Mechanical strength behaviour, Cem. Concr. Res. 29 (1999) 1313-1321. https://ac.elscdn.com/S0008884699001544/1-s2.0-S0008884699001544-main.pdf?_tid=9e5037fb7df7-482b-b391-

4a704f07c3a7\&acdnat=1536741839_807de6f9ecf31e8d7118384025d69e7e (accessed September 12, 2018).

[21] F. Pacheco-Torgal, J.A. Labrincha, C. Leonelli, A. Palomo, P. Chindaprasirt, Handbook of alkali-activated cements, mortars and concretes, Woodhead P, Sawston, RoyaumeUni, Cambridge, Royaume-Uni, 2015.

[22] B. Lothenbach, A. Gruskovnjak, Hydration of alkali-activated slag: thermodynamic modelling, Adv. Cem. Res. 19 (2007) 81-92. https://doi.org/10.1680/adcr.2007.19.2.81.

[23] R.J. Myers, S.A. Bernal, J.L. Provis, Phase diagrams for alkali-activated slag binders, Cem. Concr. Res. 95 (2017) 30-38. https://doi.org/10.1016/j.cemconres.2017.02.006.

[24] S.A. Bernal, R. San Nicolas, R.J. Myers, R. Mejía De Gutiérrez, F. Puertas, J.S.J. Van Deventer, J.L. Provis, $\mathrm{MgO}$ content of slag controls phase evolution and structural changes induced by accelerated carbonation in alkali-activated binders, Cem. Concr. Res. 57 (2014) 33-43. https://doi.org/10.1016/j.cemconres.2013.12.003.

[25] R. Tänzer, A. Buchwald, D. Stephan, Effect of slag chemistry on the hydration of alkaliactivated blast-furnace slag, Mater. Struct. 48 (2015) 629-641.

[26] C. Houzé, Etude de la valorisation des laitiers de l'industrie sidérurgique et de production des alliages silicomanganèse, Université Paris-Est, 2013.

[27] K.C. Newlands, M. Foss, T. Matchei, J. Skibsted, D.E. Macphee, Early stage dissolution characteristics of aluminosilicate glasses with blast furnace slag-and fly-ash-like compositions, J. Am. Ceram. Soc. $100 \quad$ (2017) 1941-1955. https://doi.org/10.1111/jace.14716.

[28] G. Van Rompaey, Etude de la réactivité des ciments riches en laitier, à basse température et à temps court, sans ajout chloruré., Université Libre de Bruxelles Faculté, 2006.

[29] F. Bellmann, J. Stark, Activation of blast furnace slag by a new method, Cem. Concr. Res. 39 (2009) 644-650.

[30] A. Gruskovnjak, B. Lothenbach, L. Holzer, F. Winnefeld, Hydration of Alkali Activated Slag : Comparison with Ordinary Portland Cement, Adv. Cem. Res. 3 (2006) 119-128.

[31] M. Ben Haha, G. Le Saout, F. Winnefeld, B. Lothenbach, M. Ben Haha, G. Le Saout, F. Winnefeld, B. Lothenbach, Influence of activator type on hydration kinetics, hydrate assemblage and microstructural development of alkali activated blast-furnace slags, Cem. Concr. Res. 41 (2011) 301-310.

[32] A. Fernández-Jiménez, F. Puertas, I. Sobrados, J. Sanz, Structure of Calcium Silicate Hydrates Formed in Alkaline-Activated Slag: Influence of the Type of Alkaline Activator, J. Am. Ceram. Soc. 86 (2003) 1389-94. 
[33] G. Habert, J.B. D’Espinose De Lacaillerie, N. Roussel, An environmental evaluation of geopolymer based concrete production: Reviewing current research trends, J. Clean. Prod. (2011).

[34] M. Weil, K. Dombrowski, A. Buchwald, Life-cycle analysis of geopolymers, in: J.L. Provis, J.S.J.B.T.-G. van Deventer (Eds.), Geopolymers. Struct. Process. Prop. Ind. Appl., Woodhead Publishing Series in Civil and Structural Engineering, Cambridge, UK, 2009: pp. 194-210. https://doi.org/https://doi.org/10.1533/9781845696382.2.194.

[35] I. Garcia-Lodeiro, A. Palomo, A. Fernández-Jiménez, Crucial insights on the mix design of alkali-activated cement-based binders, in: Handb. Alkali-Activated Cem. Mortars Concr., Elsevier Inc., 2014: pp. 49-73. https://doi.org/10.1533/9781782422884.1.49.

[36] K.H. Yang, J.K. Song, A.F. Ashour, E.T. Lee, Properties of cementless mortars activated by sodium silicate, Constr. Build. Mater. 22 (2008) 1981-89.

[37] M. Chi, Effects of dosage of alkali-activated solution and curing conditions on the properties and durability of alkali-activated slag concrete, Constr. Build. Mater. 35 (2012) 240-245. https://doi.org/10.1016/j.conbuildmat.2012.04.005.

[38] S.-D. Wang, K.L. Scrivener, Hydration Products of Alkali Activated Slag Cement, Cem. End Concr. Res. 25 (1995) 561-571. https://api-istex-fr.docelec.insalyon.fr/document/31C4FFC95DF244378C520D09D9738551159626E5/fulltext/pdf?aut $\mathrm{h}=\mathrm{ip}$,fede\&sid=ebsco (accessed October 12, 2017).

[39] F. Puertas, M. Palacios, H. Manzano, J.S. Dolado, A. Rico, J. Rodríguez, A model for the C-A-S-H gel formed in alkali-activated slag cements, J. Eur. Ceram. Soc. 31 (2011) 2043-2056. https://doi.org/10.1016/j.jeurceramsoc.2011.04.036.

[40] R. Fernández, E. Torres, A.I. Ruiz, J. Cuevas, M. Cruz Alonso, J. Luis García Calvo, E. Rodríguez, M. Jesús Turrero, Interaction processes at the concrete-bentonite interface after 13 years of FEBEX-Plug operation. Part II: Bentonite contact, Phys. Chem. Earth. 99 (2017) 49-63. https://doi.org/10.1016/j.pce.2017.01.009.

[41] C. Shi, R.L. Day, A Calorimetric Study of Early Hydration of Alkali-Sag Cements, Cem. Connete Res. 25 (1995) 1333-1346. https://api-istex-fr.docelec.insalyon.fr/document/C4768A62F7F1B411A20A4CD6DF8202B1992A6C4A/fulltext/pdf? auth=ip,fede\&sid=ebsco (accessed October 12, 2017).

[42] F.A. Miller, C.H. Wilkins, Infrared Spectra and Characteristic Frequencies of Inorganic Ions Their Use in Qualitative Analysis, Anal. Chem. 24 (1952) 1253-1294. http://matematicas.udea.edu.co/ carlopez/ac60068a007.pdf (accessed February 21, 2019).

[43] H. Wijnja, C.P. Schulthess, ATR-FTIR and DRIFT spectroscopy of carbonate species at the aged k-Al 2 O 3 /water interface, Spectrochim. Acta Part A. 55 (1999) 861-872. https://api-istex-fr.docelec.insa-lyon.fr/ark:/67375/6H6-W2250PT4-

Z/fulltext.pdf?auth=ip,fede\&sid=ebsco,istex-view (accessed June 6, 2019).

[44] M.A. Trezza, A.E. Lavat, Analysis of the system 3CaO.Al2O3 - CaSO4.2H2O - CaCO3 - H2O by FT-IR spectroscopy, Cem. Concr. Res. 31 (2001) 869-872. https://api-istexfr.docelec.insa-lyon.fr/ark:/67375/6H6-0TRL2L4V-

4/fulltext.pdf?auth=ip,fede\&sid=ebsco,istex-view (accessed September 2, 2019).

[45] R. Ylmén, U. Jäglid, B.M. Steenari, I. Panas, Early hydration and setting of Portland cement monitored by IR, SEM and Vicat techniques, Cem. Concr. Res. 39 (2009) 433439. https://doi.org/10.1016/j.cemconres.2009.01.017.

[46] M. Horgnies, J.J. Chen, C. Bouillon, Overview about the use of Fourier Transform Infrared spectroscopy to study cementitious materials, in: C.A. Brebbia, A. Klemm (Eds.), Mater. Characterisation VI. Comput. Methods Exp., WIT Press, Southampton, U.K, 2013: p. 364. https://doi.org/10.2495/MC130221.

[47] Z.S. Nickolov, O. Ozcan, J.D. Miller, FTIR analysis of water structure and its 
significance in the flotation of sodium carbonate and sodium bicarbonate salts, Colloids

Surfaces A Physicochem. Eng. Asp. 224 (2003) 231-239. https://doi.org/10.1016/S0927-7757(03)00317-0.

[48] K. Nakamoto, M. Margoshes, R.E. Rundlb Yol, B. Kazuo Nakamoto, R.E. Rundle, N. $\mathrm{Cl}$, Stretching Frequencies as a Function of Distances in Hydrogen Bonds, J. Am. Chem. Soc. 77 (1955) 6480-86. https://pubs.acs.org/sharingguidelines (accessed September 2, 2019).

[49] Y. Zuo, M. Nedeljković, G. Ye, Coupled thermodynamic modelling and experimental study of sodium hydroxide activated slag, Constr. Build. Mater. 188 (2018) 262-279. https://doi.org/10.1016/j.conbuildmat.2018.08.087.

[50] J.T. Kloprogge, L. Hickey, R.L. Frost, FT-Raman and FT-IR spectroscopic study of synthetic Mg/Zn/Al-hydrotalcites, J. Raman Spectrosc. 35 (2004) 967-974. https://doi.org/10.1002/jrs.1244.

[51] E. Kapeluszna, Ł. Kotwica, A. Różycka, Ł. Gołek, Incorporation of Al in C-A-S-H gels with various $\mathrm{Ca} / \mathrm{Si}$ and $\mathrm{Al} / \mathrm{Si}$ ratio: Microstructural and structural characteristics with DTA/TG, XRD, FTIR and TEM analysis, Constr. Build. Mater. 155 (2017) 643-653. https://doi.org/10.1016/j.conbuildmat.2017.08.091.

[52] P. Yu, R. J. Kirkpatrick, B. Poe, P. F. McMillan, C. Xiandong, Structure of Calcium Silicate Hydrate (C-S-H): Near-, Mid-, and Far-Infrared Spectroscopy, J. Am. Ceram. Soc. 82 (1999) 742-748. https://doi.org/10.1111/j.1151-2916.1999.tb01826.x.

[53] A. Gmira, Etude structurale et thermodynamique d'hydrates modèles du ciment, Université d'Orléans, 2003. https://tel.archives-ouvertes.fr/tel-00006001/document (accessed May 18, 2018).

[54] I.G. Lodeiro, D.E. Macphee, A. Palomo, A. Fernández-Jiménez, Effect of alkalis on fresh C-S-H gels. FTIR analysis, Cem. Concr. Res. 39 (2009) 147-153. https://doi.org/10.1016/j.cemconres.2009.01.003.

[55] Y. Mohassab, H.Y. Sohn, Analysis of Slag Chemistry by FTIR-RAS and Raman Spectroscopy: Effect of Water Vapor Content in $\mathrm{H} 2-\mathrm{H} 2 \mathrm{O}-\mathrm{CO}-\mathrm{CO} 2$ Mixtures Relevant to a Novel Green Ironmaking Technology, Steel Res. Int. 86 (2015) 740-752. https://doi.org/10.1002/srin.201400186.

[56] C. Kedziora, Propriétés d'usage et mécanismes d'hydratation du système ternaire [Ciment Alumineux - Sulfate de Calcium - Laitier de Haut Fourneau] à haute teneur en sulfate de calcium : de l'approche expérimentale à la modélisation, Institut National des Sciences Appliquées de Lyon, $2015 . \quad \mathrm{http}: / /$ theses.insalyon.fr/publication/2015ISAL0047/these.pdf (accessed April 24, 2019).

[57] B. Walkley, R. San Nicolas, M.A. Sani, G.J. Rees, J. V. Hanna, J.S.J. van Deventer, J.L. Provis, Phase evolution of C-(N)-A-S-H/N-A-S-H gel blends investigated via alkaliactivation of synthetic calcium aluminosilicate precursors, Cem. Concr. Res. (2016). https://doi.org/10.1016/j.cemconres.2016.08.010.

[58] B. Yuan, Q.L. Yu, H.J.H. Brouwers, Evaluation of slag characteristics on the reaction kinetics and mechanical properties of $\mathrm{Na} 2 \mathrm{CO} 3$ activated slag, Constr. Build. Mater. 131 (2017) 334-346. https://doi.org/10.1016/j.conbuildmat.2016.11.074.

[59] E. L 'hôpital, B. Lothenbach, K. Scrivener, D.A. Kulik, E. L'Hôpital, B. Lothenbach, K. Scrivener, D.A. Kulik, E. L 'hôpital, B. Lothenbach, K. Scrivener, D.A. Kulik, Alkali uptake in calcium alumina silicate hydrate (C-A-S-H), Cem. Concr. Res. 85 (2016) 122136. https://doi.org/10.1016/j.cemconres.2016.03.009.

[60] I. Lecomte, C. Henrist, M. Liégeois, F. Maseri, A. Rulmont, R. Cloots, (Micro)-structural comparison between geopolymers, alkali-activated slag cement and Portland cement, J. $\begin{array}{lllll}\text { Eur. } & \text { Ceram. } & \text { Soc. } & 26 & \text { (2006) }\end{array}$ https://doi.org/10.1016/j.jeurceramsoc.2005.12.021. 
[61] V.S. Ramachandran, R.M. Paroli, J.J. Beaudoin, A.H. Delgado, Handbook of thermal analysis of construction materials, William Andrew Publishing, Norwich, New, York, USA, 2002. https://doi.org/10.1016/S0040-6031(03)00230-2.

[62] E. Tajuelo Rodriguez, K. Garbev, D. Merz, L. Black, I.G. Richardson, Thermal stability of C-S-H phases and applicability of Richardson and Groves' and Richardson C-(A)-S$\mathrm{H}(\mathrm{I})$ models to synthetic C-S-H, Cem. Concr. Res. 93 (2017) 45-56. https://doi.org/10.1016/j.cemconres.2016.12.005.

[63] S. Grangeon, F. Claret, Y. Linard, C. Chiaberge, X-ray diffraction : a powerful tool to probe and understand the structure of nanocrystalline calcium silicate hydrates, Acta Cryst. B69 (2013) 465-473. https://doi.org/10.1107/S2052519213021155.

[64] J.E. Oh, P.J.M. Monteiro, S.S. Jun, S. Choi, S.M. Clark, The evolution of strength and crystalline phases for alkali-activated ground blast furnace slag and fly ash-based geopolymers, Cem. Concr. Res. 40 (2010) 189-196. https://doi.org/10.1016/j.cemconres.2009.10.010.

[65] R.J. Myers, S.A. Bernal, J.D. Gehman, J.S.J. Van Deventer, J.L. Provis, The role of Al in cross-linking of alkali-activated slag cements, J. Am. Ceram. Soc. 98 (2015) 9961004. https://doi.org/10.1111/jace.13360.

[66] G.K. Sun, J.F. Young, R.J. Kirkpatrick, The role of Al in C-S-H: NMR, XRD, and compositional results for precipitated samples, Cem. Concr. Res. 36 (2006) 18-29. https://doi.org/10.1016/j.cemconres.2005.03.002.

[67] T. Runčevski, R.E. Dinnebier, O. V. Magdysyuk, H. Pöllmann, Crystal structures of calcium hemicarboaluminate and carbonated calcium hemicarboaluminate from synchrotron powder diffraction data, Acta Crystallogr. Sect. B Struct. Sci. 68 (2012) 493-500. https://doi.org/10.1107/S010876811203042X.

[68] G. Renaudin, A. Mesbah, B.Z. Dilnesa, M. Francois, B. Lothenbach, Crystal Chemistry of Iron Containing Cementitious AFm Layered Hydrates, Curr. Inorg. Chem. 5 (2015).

[69] M. Sik Kim, Y. Jun, C. Lee, J. Eun Oh, Use of $\mathrm{CaO}$ as an activator for producing a pricecompetitive non-cement structural binder using ground granulated blast furnace slag, Cem. Concr. Res. 54 (2013) 208-214. https://doi.org/10.1016/j.cemconres.2013.09.011.

[70] W. Sha, Differential scanning calorimetry study of the hydration products in portland cement pastes with metakaolin replacement, Adv. Build. Technol. 1 (2007) 881-888. https://doi.org/10.1016/b978-008044100-9/50111-x.

[71] N. Mobasher, S.A. Bernal, J.L. Provis, Structural evolution of an alkali sulfate activated slag cement, J. Nucl. Mater. (2016). https://doi.org/10.1016/j.jnucmat.2015.11.016.

[72] K.J.D. Mackenzie, R.H. Meinhold, B.L. Sherriffb, Z. Xub, 27AI and 25Mg Solid-state Magic-angle Spinning Nuclear Magnetic Resonance Study of Hydrotalcite and its Thermal Decomposition Sequence, J. Mater. Chem. 3 (1993) 263. https://pubs-rscorg.docelec.insa-lyon.fr/en/content/articlepdf/1993/jm/jm9930301263 (accessed May 8, 2019).

[73] A. Wilkinson, A. Haque, J. Kodikara, Stabilisation of clayey soils with industrial byproducts: part A, 3 (2010) 149-163. https://doi.org/10.1680/grim.2010.163.3.149.

[74] J.-P. Jolivet, De la solution à l'oxyde. Condensation des cations en solution aqueuse. Chimie de surface des oxydes, InterEditions / CNRS Editions, Paris, France, 1994.

[75] R.K. Iler, The Chemistry of Silica: Solubility, Polymerization, Colloid and Surface Properties, and Biochemistry, John Wiley \& Sons, Inc., New York, USA, 1979.

[76] I.G. Richardson, The nature of C-S-H in hardened cements, 1999. https://api-istexfr.docelec.insa-lyon.fr/ark:/67375/6H6-3KRV35PR-

T/fulltext.pdf?auth=ip,fede\&sid=ebsco,istex-view (accessed April 26, 2019).

[77] S.A. Bernal, R. San Nicolas, J.S. J van Deventer, J.L. Provis Professor, Alkali-activated slag cements produced with a blended sodium carbonate/sodium silicate activator, (n.d.). 
https://doi.org/10.1680/jadcr.15.00013.

[78] R.J. Myers, S.A. Bernal, J.L. Provis, A thermodynamic model for C-(N-)A-S-H gel: CNASH_ss. Derivation and validation, Cem. Concr. Res. 66 (2014) 27-47. https://doi.org/10.1016/j.cemconres.2014.07.005.

[79] P.W. Brown, The System Na20-Ca0-SiOrH20, J. Am. Ceram. Soc. 73 (1990) 3457-61. https://ceramics-onlinelibrary-wiley-com.docelec.insa-lyon.fr/doi/pdf/10.1111/j.11512916.1990.tb06475.x (accessed June 21, 2019).

[80] B. Lothenbach, A. Nonat, Calcium silicate hydrates: Solid and liquid phase composition, Cem. Concr. Res. 78 (2015) 57-70. https://doi.org/10.1016/j.cemconres.2015.03.019.

[81] Rupert J. Myers, Emilie L'Hôpital, John L. Provis, Barbara Lothenbach, Compositionsolubility-structure relationships in calcium (alkali) aluminosilicate hydrate, R. Soc. Chem. (2015). http://pubs.rsc.org/en/content/articlepdf/2015/dt/c5dt01124h (accessed March 2, 2018).

[82] V.O. Özçelik, C.E. White, Nanoscale Charge-Balancing Mechanism in AlkaliSubstituted Calcium-Silicate-Hydrate Gels, J. Phys. Chem. Lett. 7 (2016) 5266-5272. https://doi.org/10.1021/acs.jpclett.6b02233. 